\title{
REGULATORY REVIEW IN ANTI-REGULATORY TIMES
}

\author{
DANIEL A. FARBER*
}

\section{INTRODUCTION}

The 2016 elections put the Republican Party firmly in control of Congress and the White House. After a year in office, President Trump proudly announced that "[n]o president has ever cut so many regulations in their entire term, O.K., as we have cut in less than a year." On this issue, at least, he was firmly aligned with Republican orthodoxy. In 2016, the Republican-controlled House of Representatives had passed a bill to require congressional approval before any major new regulation could go into effect, in a bid to reduce what Speaker Paul Ryan termed excessive regulation. ${ }^{2}$ The ensuing period included rulemakings to repeal major regulations on issues such as climate change, as well as congressional interventions to overturn over twenty other regulations. ${ }^{3}$

Since the beginning of Ronald Reagan's presidency, cost-benefit analysis (CBA) has been an integral part of the regulatory process. For nearly forty years, regulatory agencies like the Environmental Protection Agency

- Sho Sato Professor of Law, University of California, Berkeley. I would like to thank Erica Sun for unearthing and compiling the data on the Congressional Review Act discussed later in this article. Jonathan Masur and Richard Pierce provided very helpful comments.

1. Linda Qui, Trump Says 'No President Has Ever Cut So Many Regulations. ' Not Quite., N.Y. TIMES (Feb. 23, 2018), https:/www.nytimes.com/2018/02/23/us/politics/trump-says-no-president-hasever-cut-so-many-regulations-not-quite.html [https://perma.cc/4DWE-XWHV].

2. Press Release, U.S. Congressman Paul Ryan, Reining in Regs (Jan. 5, 2017).

3. Regarding the Trump Administration's early activities, Gillian Metzger observes that:

These actions include specific area rollbacks, such as instructions that agencies repeal, waive, or delay implementation of major Obama Administration regulatory initiatives in the environmental, financial regulation, and health care arenas. But they also encompass dramatic transsubstantive measures, in particular requirements that agencies establish task forces focused on regulatory repeal, repeal two regulations for each new regulation they propose, and keep additional regulatory costs at zero. President Trump's cabinet is composed of individuals who have long opposed the agencies and programs they now lead and his budget proposes to dramatically slash funding for a large swath of nonmilitary agencies.

Gillian E. Metzger, Foreword: 1930s Redux: The Administrative State under Siege, 131 HARV. L. REV. 1, 9-10 (2017). As we will see, Trump used executive orders to implement some of the failed legislation. Metzger also notes that "[b]usiness interests are enjoying a regulatory retraction of unprecedented proportions, with the combination of executive branch actions and Congress's disapproval of late Obama Administration rules under the CRA [Congressional Review Act]." Id. a 10. 
(EPA) have been required to perform cost-benefit analyses that are subject to review by the Office of Information and Regulatory Affairs (OIRA), which is part of the Office of Management and Budget (OMB) in the White House. ${ }^{4}$ Most of the focus, however, has been on how cost-benefit analysis (CBA) operates in the context of expanded regulation, not repeal of existing regulations. This article investigates the role of CBA in a period when the government's major thrust is eliminating regulation, rather than expanding it. This deregulatory period has had some novel features, including the first vigorous use by Congress of its power to overturn recently issued regulations and the layering of novel deregulatory mechanisms on top of cost-benefit analysis. It also presents important examples of sharply reversed CBAs, in which the same regulations that were said to have large net benefits under Obama are instead said to have net costs under Trump. As yet, there has been no comprehensive description or analysis of these developments.

These developments need to be put in the context of the long-running dispute over CBA. Although many economists and some legal scholars favor the use of cost-benefit analysis for government regulation, ${ }^{5}$ environmentalists and other progressives are often sharply opposed. ${ }^{6}$ For instance, two leading environmentalist critics of $\mathrm{CBA}^{7}$ contend that "cost-benefit analysis promotes a deregulatory agenda under the cover of scientific ob-

4. For a description of the development of OMB's role in regulatory oversight, along with some useful suggestions for improving cost-benefit analysis, see Daniel H. Cole, "Best Practice" Standards for Regulatory Benefit-Cost Analysis, 23 RES. L. \& ECON. 1 (2007). MATTHEW D. ADLER \& ERIC A. POSNER, COST-BENEFIT ANAlySis: ECONOMIC, PHILOSOPHICAL, AND LegAl PERSPECTIVES (2001), collects papers reflecting the spectrum of views about CBA and its validity. A description of the rise of attention to CBA in the legal academy can be found in Don Bradford Hardin, Jr., Why Cost-Benefit Analysis? A Question (and Some Answers) About the Legal Academy, 59 ALA. L. REV. 1135, 1135-36 (2008). Finally, for information about the operation of OMB in the Obama Administration, see Cass $R$. Sunstein, The Office of Information and Regulatory Affairs: Myths and Realities, 126 HARV. L. REV. 1838 (2013). note 4

5. For an introduction to opposing views of cost-benefit analysis, see ADLER \& POSNER, supra

6. For citations to some of the key critical works, see Douglas A. Kysar, It Might Have Been: Risk, Precaution, and Opportunity Costs, 22 J. LAND USE \& ENVTL. L. 1, 6 n.23 (2006).

7. They make it clear, however, that their quarrel is with the economic methodology of costbenefit analysis, not with taking costs and benefits into account:

[A]nalysis of costs and benefits, in lowercase letters, is an essential part of any systematic thought about public policy, and has always been involved in government decision making.

Our criticism concerns the much narrower doctrine of Cost-Benefit Analysis, which calls for

a specific, controversial way of expressing and thinking about costs and benefits.

Frank ACKERMan \& LiSA Heinzerling, PRICEless: ON KNOWING THE PRICE OF EVERYTHING AND THE VALUE OF NOTHING 211 (2004). 
jectivity."8 In particular, they argue that cost-benefit analysis requires analysts to settle on numbers for all costs and benefits, regardless of uncertainty, putting pressure on them to ignore uncertainties completely or to ignore more extreme possibilities even when they do acknowledge variability. ${ }^{9}$ If these critics are right that CBA is only a façade for anti-regulatory politics, we would expect it to fit smoothly with Trump Administration policy.

Unlike these critics, some writers who are sympathetic to environmental protection embrace cost-benefit analysis. ${ }^{10}$ Although they view it as just one input into the ultimate regulatory decision, ${ }^{11}$ Richard Revesz and Michael Livermore argue that cost-benefit analysis is needed to determine when further spending on risk reduction is no longer worthwhile. ${ }^{12}$ They contend that, just as environmental impacts of actions must be taken into account, so should economic impacts of regulation. ${ }^{13}$ They also view costbenefit analysis as a way to discipline the wide discretion given to administrative agencies, thereby ensuring that decisions are made on the basis of reasoned analysis and uniform criteria. ${ }^{14}$ If advocates of CBA are right that CBA functions in the administrative state as a neutral check on government initiatives, deregulatory policies should be as much restricted by CBA as regulatory ones.

Both the addition of new regulatory restrictions on top of CBA and the exercise of congressional overrides on regulations that have passed CBA indicate a lack of confidence in CBA as a check on ill-advised regulations. Thus, it would appear, a considerable number of conservatives have doubts about the neutrality and objectivity of CBA in practice. ${ }^{15}$ Advocates of

8. Id. at 9. See also id. at 11-12 ("Cloaked in the language of scientific objectivity, economic arguments have repeatedly played a partisan role.").

9. Id. at 225.

10. For a references to the writings of some of the leading academic supporters of cost-benefit analysis, see Kysar, supra note 6 , at 5 .

11. Id. at 15 .

12. RICHARD L. REVESZ \& MichaEl A. LIVERMORE, RETAKING RATIONALITY: How COSTBenEFIT ANALYSIS CAN BETTER PROTECT THE ENVIRONMENT AND OUR HEALTH 12 (2008).

13. Id. at 13 .

14. Id.

15. Consider the following comments by a noted administrative law scholar:

I've testified now four times before various congressional committees on various versions of what is called the Regulatory Budget Act. What the opponents of EPA are arguing is that we need a regulatory budget that ignores benefit and considers costs only. My defense every time is, no-cost-benefit analysis should be the basis for decisionmaking. Cost-benefit analysis is now on the left end of the political spectrum.

The Future of Administrative Law, 47 ENVTL. L. REP. NEWS \& ANALYSIS 10186, 10195 (2017) (remarks of Richard J. Pierce). 
CBA, whether economists or sympathetic legal scholars, are thus under pressure from critics on both sides.

This article seeks to improve our understanding of regulatory review, including CBA, by studying its use in a period of sustained deregulatory activities. Even a law review is unlikely to require a citation for the assertion that Donald Trump is not a typical American president-an assertion that neither President Trump nor his critics would contest. Thus, there are limits to how much we can extrapolate from the current period. On the other hand, as shown by Congress's flexing of its own muscles to disapprove regulations, on this point Trump's goals are those of his party. Moreover, a number of his initiatives echo earlier unsuccessful legislative efforts by the party. Thus, this period may be less exceptional in the realm of regulatory policy than other aspects of the Trump Presidency.

The article's examination of recent developments in regulatory review proceeds as follows. Part I examines the role of OIRA in the Trump era. OIRA has been given new responsibilities on top of its existing regulatory review functions. Although the evidence is still scattered, it does provide some indications of how OIRA is handling its traditional functions. Part II turns to regulatory review in Congress. Until 2017, Congress had only once exercised its authority under the Congressional Review Act to overturn regulations. In 2017, however, it made vigorous use of this authority to eliminate a host of newly issued regulations. This use of congressional authority deserves closer investigation. Part III then looks at how CBA is operating at the agency level. A comprehensive survey across the entire government is impractical. Instead, Part IV focuses on a single regulatory agency, the Environmental Protection Agency (EPA). Finally, I offer a summary and some concluding thoughts.

The developments discussed in this article are only one part of a larger attack on the regulatory state. As Gillian Metzger has observed, the current anti-regulatory movement is reminiscent of attacks on the legitimacy of the administrative state in the 1930s. ${ }^{16}$ The attacks are characterized by emotionally charged rhetoric. Metzger notes that "[m]uch advocacy for these legislative and regulatory measures describes administrative government in harsh terms, for example invoking the need to rein in an 'out-of-control bureaucracy' intent on imposing costly, 'job-crushing' regulations." 17 The

16. Metzger, supra note 3, at 6.

17. Id. at 13 (quoting 163 CONG. REC. H900 (daily ed. Feb. 2, 2017) (statement of Rep. Walorski on H.R.J. Res. 40, 115th Cong. (2017)), and President Donald J. Trump, Remarks in Joint Address to 
larger issues presented by this anti-regulatory movement are beyond the scope of this article. But, as we will see, one of the current effects of this movement is to reduce the centrality of analytic approach to regulation represented by cost-benefit analysis, largely in favor of a heavy emphasis on regulatory costs as opposed to benefits.

This heavy emphasis on costs in the administrative process represents a fundamental shift in regulatory philosophy. The core argument for costbenefit analysis is that it is simply irrational to make decisions without taking into account costs and benefits, and that this can best be done through economic analysis. As one prominent advocate for cost-benefit analysis has said, "It is not possible to do evidence-based, data-driven without assessing both costs and benefits, and without being as quantitative as possible." 18 Fixating on costs while downplaying benefits is in considerable tension with this vision of rational decision making. It is even harder to connect Congress's use of the Congressional Review Act to either a concern about net benefits or a desire to reduce the economic burdens of regulation. Our examination suggests a haphazard use of congressional review with no obvious driving mission.

\section{A SHORT PRIMER ON COST-BENEFIT ANALYSIS}

Shortly after taking office President Reagan signed Executive Order $12,291,19$ aimed at improving the efficiency of informal rulemaking by executive agencies. Section 2 directed that "major" regulations not be promulgated unless, "taking into account affected industries [and] the condition of the national economy," the potential benefits to society outweigh potential costs, and net benefits are at a maximum. Review of agency costbenefit analyses was conducted by the Office of Management and Budget. In 1993, President Clinton issued an executive order maintaining the basic approach but attempting to streamline the process of OMB review. The rule was intended to reduce the number of regulations sent to OMB for approval

Congress (Feb. 28, 2017), https://www.whitehouse.gov/the-press-office/2017/02/28/remarks-presidenttrump-joint-addresscongress [https://perma.cc/ULB9-VMKB]).

18. Cass R. Sunstein, Adm'r, Office of Info. \& Regulatory Affairs, Humanizing Cost-Benefit Analysis, Remarks Prepared for American University's Washington College of Law Administrative Law Review Conference 13 (Feb. 17, 2010). See also Cass R. Sunstein, Is Cost-Benefit Analysis for Everyone?, 53 ADMIN. L. REV. 299, 300 (2001) ("“[]t would be premature to say that CBA has received the kind of social consensus now commanded by economic incentives and deregulation of airlines, trucking and railroads. 1 believe that CBA should command such a consensus, at least as a presumption, and that the presumption in favor of CBA should operate regardless of political commitments.").

19. Exec. Order No. 12,291, 46 Fed. Reg. 13,193 (Feb. 17, 1981). 
and to make OMB's review more flexible. ${ }^{20}$ President George W. Bush appointed John D. Graham from the Harvard Center for Risk Analysis, to head the Office of Information and Regulatory Affairs (OIRA) in the Office of Management and Budget. ${ }^{21} \mathrm{He}$ was the subject of sharp criticism by public interest groups. ${ }^{22}$ Upon taking office, President Obama rescinded President Bush's executive orders on cost-benefit analysis. Essentially, the government then reverted to the Clinton-era version of the cost-benefit mandate. To the surprise of many observers, the Obama Administration turned out to be a staunch supporter of cost-benefit analysis, requiring rigorous documentation in support of proposed regulations. ${ }^{23}$

The "cost" side of CBA is relatively straightforward, at least in principle, since the central concern is the direct economic impact of a regulation on industry. But the "benefit" side can be more complex. We will consider two difficulties on the benefit side of the analysis: the difficulty of determining monetary measures for environmental benefits and the fact that these benefits often accrue in the future while costs are more immediate.

For example, suppose an economist wanted to do a cost-benefit analysis of a method of controlling some form of water pollution. On the benefit side of the equation, the economist would need to assign values, based on willingness to pay, for the elimination of this source of pollution. Some of these values would be relatively easy to determine, given the necessary scientific information-for example, loss in profits to fishing boats caused by pollution. At least, the calculations would be straightforward in theory, although in litigation expert witnesses may differ sharply with each other about these lost profit issues. Other regulatory benefits would be more difficult to measure in monetary terms, such as benefits to endangered species or improvements in public health.

One major valuation issue involves putting a monetary value on reductions in mortality risks. Without worrying right now about the technicalities, economists can assign monetary values to different levels of risk

20. See Ellen Siegler, Executive Order 12866: An Analysis of the New Executive Order on Regulatory Planning and Review, 24 ENVTL. L. REP. 10070 (1994).

21. Thomas O. McGarity, The Story of the Benzene Case: Judicially Imposed Regulatory Reform through Risk Assessment, in ENVIRONMENTAL LAW STORIES 141, 169 (Richard J. Lazarus \& Oliver A. Houck eds., 2005).

22. According to McGarity, under Graham's leadership, "OIRA greatly stemmed the flow of health, safety and environmental regulation during the Bush Administration. Although EPA promulgated several important regulations, most of which were required by statute, OSHA did not promulgate a single significant health standard during the entire four years." Id.

23. The head of OIRA during much of the Obama Administration wrote about his experiences in Sunstein, supra note 4. 
by looking at how much consumers are willing to pay for safer products, or at how much income workers are willing to give up for safer jobs, or at how much travel time people are willing to sacrifice for the safety benefits of driving more slowly. All of these would be different ways of determining the market value of safety.

If people demand $\$ 1,000$ in return for being exposed to a one in a thousand risk of death, it is conventional to say that the "statistical value of life" is $\$ 1$ million. This is a bit misleading, since people probably would not be willing to commit suicide for that amount of money! To express this distinction, economists often speak of the value of a statistical (as opposed to individual) life. To assign a value of $\$ 1$ million per statistical life is the same as saying that people would demand $\$ 1$ in return for running a one-ina-million chance of death.

Often, the costs and benefits of a regulatory measure occur at different times. When the costs accrue today but the benefits are in the future, we need some method of taking the time factor into account. Global warming or endangered species provide obvious examples because the effects of our policy choices are multi-generational. Long-term delayed harms are ubiquitous, however, in environmental law. As Lisa Heinzerling points out: "[r]adioactive substances are perhaps the most dramatic example of such a long-lived threat" as shown by EPA's determination that "the disposal site must be one that will remain undisturbed for at least 10,000 years." ${ }^{24}$ Nor does this example stand alone:

Other persistent contaminants include [PCBs, DDT], chlordane, dieldrin, and dioxin. These can persist in the environment, and in human tissue, for many years. ... While the precise definition of "persistence" remains largely political and practical rather than scientific, it nonetheless remains true that today's use and disposal of radioactive substances, chlorinated organic compounds, and heavy metals will continue to pose threats to human health for many decades, in some cases centuries, to come. ${ }^{25}$

For this reason, discounting plays a key part in the economic analysis of environmental regulation. ${ }^{26}$

24. Lisa Heinzerling, The Temporal Dimension in Environmental Law, 31 ENVTL. L. REP. 11055, 11066-67 (2001).

25. Id. at 11067 .

26. An overview of the economics of discounting can be found in Elizabeth Atherton, From Discounting to Incorporating Decisions' Long-Term Impacts, 11 RISK: HEALTH, SAFETY, \& ENV'T 125 (2000). 
The basic idea of discounting is simple. If $\$ 1000$ invested at compound interest today will produce $\$ 2000$ in five years, we "discount" the $\$ 2000$ at the same interest rate, concluding that the "present value" of $\$ 2000$ receivable in five years is $\$ 1000$ today. ${ }^{27}$ Making this adjustment allows us to compare different investments whose payoffs have varying time profiles. For instance, suppose we are comparing two different contracts. If one contract pays $\$ 1500$ today, we know that it is a better deal than another which pays $\$ 2000$ in five years for the same price, because we can take the $\$ 1500$, invest it, and have more than $\$ 2000$ in five years. The shorthand way of saying this is that the present value of the first contract is $\$ 1500$, while the present value of the other is only $\$ 1000$.

Over long time periods, the results of changes in discount rates are enormous, as Cass Sunstein explains: "[i]f a human life is valued at $\$ 8$ million, and if an agency chooses a ten percent discount rate, a life saved 100 years from now is worth only $\$ 581 . " 28$ Thus, what seems at first blush to be an abstruse technical issue turns out to have a grave significance in evaluating long-term regulatory decisions. Discounting is particularly controversial in the multigenerational context. Much of the regulatory debate under the Obama and Trump Administrations has involved climate change, a very long-term problem. A ton of $\mathrm{CO}_{2}$ emitted today will stay in the atmosphere an average of two to three centuries, continuing to cause climate impacts, and global temperatures will remain high, even after we eliminate emissions, for an even longer time. ${ }^{29}$ Conversely, a dollar invested in reducing emissions today will provide benefits over the same period of time. In assessing the value of this investment, we need to take into account the long timespan involved.

The basic concept behind discounting is that people generally prefer consumption today over consumption tomorrow. Suppose someone has the choice between getting some amount of money today and $\$ 100$ a year from

27. A concise introduction to discounting can be found in NICHOLAS STERN, THE ECONOMICS OF Climate Change: The Stern Review 50-60 (2007). As Stern points out, uncertainty about future growth implies that the discount rate declines for events further in the future. See id. at 56-57. For some reflections on the problems raised by consideration of time in cost-benefit analysis even beyond discounting, see Arden Rowell, Time in Cost-Benefit Analysis, 4 U.C. IRVINE L. REV. 1215 (2014). An excellent overview of the debate over the Stern report can be found in Daniel H. Cole, The Stern Review and Its Critics: Implications for Theory and Practice of Cost-Benefit Analysis, 48 NAT. RESOURCES J. 53 (2008).

28. Cass R. Sunstein, Cost-Benefit Default Principles, 99 MiCH. L. REV. 1651, 1711 (2001).

29. According to Nordhaus, if we do nothing about climate change until 2100 and then stop all emissions, " $\mathrm{CO}_{2}$ concentrations would remain well above preindustrial levels for a millennium, and global temperature would peak at around $4^{\circ} \mathrm{C}$ above 1900 levels." WILliAM NORDHAUS, THE ClimATE CASINO: RISK, UNCERTAINTY, AND ECONOMICS FOR A WARMING WORLD 163 (2013). 
now. Even ignoring inflation, most people will be willing to take less than $\$ 100$ dollars today instead of waiting a year. This can be due to several factors - one of them is simple impatience for the money and what it can buy, and another is that a person might expect to have more money next year anyway, so that person would need the money more badly today. ${ }^{30}$

The discount rate measures the degree of preference for the presentfor instance, a ten percent discount rate means that receiving $\$ 100$ a year from now is only as good as receiving $\$ 90$ today (even apart from inflation). The key point is that the value of receiving a future dollar falls over time in accordance with the discount rate. Over a long period of time- the kind of time period involved with climate change-the changes are really dramatic because discounting compounds as the years go on. For instance, at a ten percent discount rate, even without inflation, $\$ 100,000$ in 2015 equates to about $\$ 7.30$ today. ${ }^{31}$

Because of the very long-term effects of climate change, discounting is a crucial factor in the economic analysis. But economists themselves find it disquieting that discounting "forces us to say that what we might otherwise conceptualize as monumental events 'do not much matter' when they occur in future centuries or millennia." 32 Even if we assume that discounting is appropriate when dealing with the effect of policies on current generations, its application to future generations raises graver issues. After all, their value as human beings is equal to that of people today, yet discounting systematically downgrades their interests, sometimes to the point of insignificance. ${ }^{33}$

30. For specificity, suppose the person in question would take $\$ 900$ today over $\$ 1000$ a year from now (but nothing less). So $\$ 900$ today equals $\$ 1000$ next year. That means that the person would only make an investment of $\$ 900$ this year if the payout is at least $\$ 1000$, an eleven percent increase. How much would person want today in exchange for $\$ 1000$ in two years? We know that $\$ 1000$ in year two equals $\$ 900$ in year one, and in turn that equals about $\$ 820$ dollars today (110 percent of $\$ 820$ is just over $\$ 900$ ). So getting $\$ 1000$ dollars in two years is equivalent to having $\$ 820$ dollars on hand today, at least if the person is being consistent. At least this is true in theory, whether human preferences actually fit this model is a different question.

31. The easiest way to generate these figures is to use an on-line app like http://www.aquacalc.com/page/discounted-present-value-calculator. Nordhaus uses another set of illustrative figures, showing that the present value of a $\$ 100$ million reduction in damages is about $\$ 60$ million at a one percent rate but falls by almost a factor of five at a four percent rate and by a about a factor of sixty-five as ten percent. NORDHAUS, supra note 29, at 191.

32. Martin L. Weitzman, Why the Far-Distant Future Should be Discounted at Its Lowest Possible Rate, 36 J. ENVTL. ECON. \& MGMT. 201, 201 (1998).

33. Some influential economists have argued that discounting should not include any reduction in present value based on the intrinsic difference between future and present consumption, as opposed to other factors such as the possibility of increasing wealth over time. See STERN, supra note 27, at 35-36. 
One defense of discounting is that funds spent to avoid climate change could be spent on other purposes, which might be more beneficial to future generations. Thus, we might want to engage in discounting in the interests of future generations in order to maximize the benefits to them of presentday investments. Market rates represent the opportunity cost of investment, so this argument suggests that we should avoid climate mitigation projects unless they offer equal returns. ${ }^{34}$ One problem with this argument, however, is that climate change might have catastrophic effects on later generations that cannot be offset by increased savings. ${ }^{35}$

If discounting is indeed a valid approach, other, more technical difficulties must be confronted. As it turns out, the number chosen as the discount rate is very important; small differences can be amplified over time into a big difference in the outcome. This can be seen from the following table:

Table 1: Effect of Discount Rate on Present Value

\begin{tabular}{|c|c|c|}
\hline $\begin{array}{l}\text { Discount } \\
\text { rate }\end{array}$ & $\begin{array}{l}\text { Present value of \$6 million } \\
\text { received in 20 years }\end{array}$ & $\begin{array}{l}\text { Present value of \$6 million } \\
\text { received in 40 years }\end{array}$ \\
\hline $10 \%$ & $\$ 894,000$ & $\$ 132,570$ \\
\hline $7 \%$ & $\$ 1,560,000$ & $\$ 400,682$ \\
\hline $5 \%$ & $\$ 2,261,337$ & $\$ 852,274$ \\
\hline $3 \%$ & $\$ 3,324,000$ & $\$ 1,839,341$ \\
\hline
\end{tabular}

As the table shows, reducing the discount rate from seven to three percent more than triples the present value of the eventual benefit over twenty years, from under $\$ 1$ million to over $\$ 3$ million. Cutting the rate an additional two percent would bring the present value up to nearly $\$ 5$ million. Over longer periods of time, the differences are even more dramatic. For instance, over forty years, raising the discount rate from three percent to seven percent reduces the present value almost eighty percent, from about

34. This argument is developed in Eric A. Posner \& David Weisbach, Climate Change JUSTICE (2010).

35. Another argument for discounting is that, given economic growth, future generations are likely to be much wealthier than current generations, even taking into account climate change. Why should present generations sacrifice to make future generations even richer-does this not in effect transferring money from the (relatively) poor to the (relatively) rich? But future growth rates may be uncertain. Even today, although technology is a constant, individual countries have much different records of growth, which suggests that other factors are also crucial. Given the limits on how well we understand growth, we may not have any real assurance that present growth rates will continue. 
$\$ 2$ million to under half a million. Over eighty years, the difference is $\$ 26,934$ versus $\$ 559,494$, an almost twenty-fold.

The bottom line is that discounting makes a big difference in assessing costs and benefits over long periods of time, and that difference is quite sensitive to changes in rates. Over multiple-decadal time scales, a minor shift in the discount rate can dramatically impact the analysis of whether additional precautions are warranted. Given the very long-term effects of climate change, a small change in the discount rate can drive huge changes in the results. Yet, there is no consensus about what discount rate to use for climate change. ${ }^{36}$

There are additional difficulties associated with measuring the value of some other environmental benefits: so-called option and existence values. An example of option value might be posed by someone who has no particular plans to go to Lake Tahoe, but who would be willing to pay something in order to keep open the option of seeing the lake again if he or she chooses to do so. Existence values are even more ethereal-for example, the amount of money a person would be willing to pay to save rain forests, although it may be extremely unlikely that she would ever go there. "Use values" flow from some direct physical interaction with a natural resource, such as recreational use of a forest. In contrast, non-use values don't involve any observable current effects. ${ }^{37}$

Many economists advocate the use of "contingent valuation" studies to measure how much people are willing to pay for non-use values. Contingent valuation is essentially a survey technique. People are given information about an environmental issue and then asked if they would be willing to pay a certain amount to solve the problem. There is a great deal of dispute about whether contingent valuation can provide a genuine measure of preferences. Cass Sunstein, for example, has argued that many contingent valuation analyses should not be taken seriously. He stressed what he described as the "astonishing and devastating fact" that willingness to pay seems constant regardless of the scale of the environmental problem. In responding to surveys, he contends, "people may be purchasing moral satisfaction rather than stating their real valuation," merely proclaiming their

36. For a concise overview of the relevant literature, see Charles Kolstad \& Kevin Urama, Social, Economic, and Ethical Concepts and Methods, in CLIMATE CHANGE 2014: MiTIGATION OF ClimATE ChaNGe: Working Group III CONTRIBUTION TO THE IPCC FIFTH ASSESSMENT REPORT 228-32 (2015).

37. For introductions to these concepts, see Christopher D. Stone, What to do About Biodiversity: Property Rights, Public Goods, and the Earth's Biological Riches, 68 S. CAL. L. REV. 577, 580-88 (1995). 
unwillingness to feel responsible for environmental harms. ${ }^{38}$ Economists critical of contingent valuation view the resulting numbers as mostly reflecting the warm glow that people get by announcing their support for the environment. These critics doubt that people actually have well-defined, coherent preferences about specific environmental sites or that their responses reflect considered efforts to assess such preferences. ${ }^{39}$

But this view is by no means universal among economists. Advocates of contingent valuation argue that the critics have exaggerated the problems, that many problems can be limited through careful survey design, and that contingent valuation can be validated against other measures of environmental benefits. Regulations governing damages for injury to public resources due to oil spills or toxic chemicals call for the application of contingent valuation, and courts have upheld this methodology. ${ }^{40}$

As this discussion indicates, cost-benefit analysis can involve difficult issues about how to assess regulatory benefits. The cost side of the analysis generally involves investments by business or increased operating costs, which are straightforward in principle but may be difficult to forecast in practice. Thus, controversy about cost-benefit analysis tends to revolve around whether benefits are being appropriately quantified.

\section{REGULATORY REVIEW IN CONGRESS}

Under the Congressional Review Act (CRA), ${ }^{41}$ Congress has the power to reject agency regulations within a limited time frame, subject to presidential veto. Under the CRA, before major rules can go into effect, agencies must notify Congress, which then has a specified period of time in which to consider a joint resolution of disapproval. If a joint resolution of disapproval becomes law, the CRA provides that a rule may not be issued in "substantially the same form" without additional statutory authorization.

38. Cass R. SunStein, FReE MARKeTS AND SoCIAL JUSTICE 142-43 (1997). For an environmentalist critique of contingent valuation, see John Heyde, Is Contingent Valuation Worth the Trouble?, 62 U. CHI. L. REV. 331 (1995).

39. See Peter Diamond \& Jerry Hausman, Contingent Valuation: Is Some Number Better Than No Number?, 8 J. ECON. PERSP. 45, 45, 56, 63 (1994); Brian Binger et al., Contingent Valuation Methodology in the Natural Resource Damage Regulatory Process: Choice Theory and the Embedding Phenomenon, 35 NAT. RESOURCES J. 443 (1995).

40. See Gen. Elec. Co. v. U.S. Dep't of Commerce, 128 F.3d 767, 772-74 (D.C. Cir. 1997) (natural resource damages for oil spills); Ohio v. U.S. Dep't of the Interior, 880 F.2d 432, 463-64 (D.C. Cir. 1989) (natural resource damages under CERLA).

41. 5 U.S.C. $\$ \S 801-808$ (2012). 
The scope of this prohibition remains unclear. ${ }^{42}$ Understanding the CRA's operation is important, not only to fill out the picture of regulatory review but also because it sheds light on the desirability of legislative proposals such as the REINS Act, which would give Congress even more control over rules. ${ }^{43}$

After Trump's election ushered in a unified government, Congress made aggressive use of the CRA against Obama Administration regulations. As Jerry Mashaw and David Berke have observed, "[a]s other GOP legislative efforts have sputtered, these CRA repeals 'arguably constitute the Trump Administration's chief domestic policy accomplishment of its first 100 days.' Although [there is little direct evidence], this CRA effort was seemingly effected through collaboration between the President and Congress, even if not all CRA resolutions were ultimately successful."44 On average, the resolutions passed Congress with numbers corresponding to the Republican majority in each house. ${ }^{45}$ The CRA's time limits preclude careful congressional consideration, and its fast-track procedural provisions can limit the normal process of deliberation. ${ }^{46}$

Based on several case studies, Daniel Cole has hypothesized that costbenefit analysis may help defuse political opposition when cost-benefit analysis is positive. ${ }^{47}$ This is a plausible hypothesis and may have particu-

42. For further detail about the CRA, see MAEVE P. CAREY ET AL., THE CONGRESSIONAL REVIEW ACT: FREQUENTLY ASKED QUESTIONS (2016), https://fas.org/sgp/crs/misc/R43992.pdf [https:// perma.cc/SUD8-PK3H].

43. On the REINS Act, see David Schoenbrod, How REINS Would Improve Environmental Protection, 21 DUKE ENVTL. L. \& POL'Y F. 347 (2011).

44. Jerry L. Mashaw \& David Berke, Presidential Administration in A Regime of Separated Powers: An Analysis of Recent American Experience, 35 YALE J. ON REG. 549, 602 (2018).

45. Thomas O. MCGarity ET AL., THE CONGRESSIONAL ReVIEW ACT: THE CASE FOR REPEAL 3 (May 2018), http://progressivereform.org/articles/CRA_Repeal_Case_050218.pdf [https://perma.cc/ VDX5-S7EQ] [hereinafter Case for Repeal]. Vice President Pence had to break ties in order to secure the passage of two of the resolutions. Id.

46. As Coglianese and Scheffler explain,

In contrast to the years that agencies spent evaluating comments and analyzing their regulations, it took Congress a mere four months on average-including congressional recessesfor both chambers to vote to repeal the fifteen regulations, mostly on party-line votes. Even if Congress wanted to take a more deliberate approach, the CRA's fast-track procedures explicitly limit the time for floor debate on resolutions of disapproval.

Cary Coglianese \& Gabriel Scheffler, What Congress's Repeal Efforts Can Teach Us About Regulatory Reform, 3 ADMIN. L. REV. ACCORD 43, 53 (2017).

47. Daniel H. Cole, Law, Politics, and Cost-Benefit Anahysis, 64 ALA. L. Rev. 55, 88 (2012). Cole suggests that "CBAs nearly always influence and can determine political outcomes, even when they are not supposed to do so under existing legal rules" and that "federal agencies, even when legally barred from considering cost, have incentives to produce and sometimes strategically manipulate CBAs to preempt or undermine political opposition to regulatory or deregulatory proposals," though this strategy can fail when the CBA is clearly flawed. Id. at 58. 
lar relevance in the context of the CRA process. The tight time frame, combined with the fact that members of Congress are generalists, ${ }^{48}$ might be expected to increase the salience of the cost-benefit analysis conducted by agencies and approved by OIRA. Republican members of Congress might well think that the Obama Administration exaggerated the benefits of regulations and undercounted the costs. Nevertheless, given a shortage of time and little specialized knowledge, a better cost-benefit ratio should be a signal of a regulation's value as compared to regulations with worse economic attributes, even if Congress believes that there is an overall favorable bias in the CBAs. By analogy, if we know that a certain professor is an easy grader, the grades may still remain informative after we compensate for that bias: an $A$ remains a better grade than a B, perhaps even more so in the case of the easy grader, for whom a B is a very low grade.

The general question of how much cost-benefit analysis actually impacts government decisions is not easy to investigate in any systematic way. It is very difficult to test the impact of cost-benefit analysis on decision-making in the executive branch, although even its most fervent advocates admit that it fades in significance when hot political issues are involved. ${ }^{49}$ The problem is that we cannot observe political influences on the cost-benefit analysis itself, so we cannot be sure whether the CBA has influenced the ultimate political decisions or whether causation runs from politics to CBA instead, with the cost-benefit tilted toward an outcome that political actors have already decided.

In contrast, the use of the Congressional Review Act in 2017 could provide a much better research setting. It seems unlikely that agencies skewed their cost-benefit analyses with potential CRA-overrides in mind. Many of the CBAs that were subject to Congressional review were probably largely completed well before the 2018 election, when there was little reason to anticipate a Trump victory. ${ }^{50}$ If Hillary Clinton had been elected President, any CRA resolutions would undoubtedly have been vetoed, so agencies had little to worry about. Thus, there is at least somewhat less reason to think that the CBAs would have been written with the prospect of congressional review in mind.

48. Id. at 54 .

49. Cass R. Sunstein, The Cost-Benefit Revolution 211 (2018).

50. Even for those regulations that were hurriedly completed in the weeks between the election and Trump's inauguration, the CBA to accompany the proposed version of the rule would probably have been completed earlier, limiting the agency's ability to make major changes credibly. 
In order to test the influence of cost-benefit analysis on CRA actions, a research assistant and I collected information on the regulations for which CRA resolutions had been introduced. ${ }^{51}$ (An Appendix contains a list of the regulations in question. ${ }^{52}$ ) The initial hope was that we would be able to determine whether net benefits, total costs, total benefits, or cost-benefit ratios were different between the regulations that were ultimately invalidated by Congress and those that were not. Sadly, such a statistical analysis turned out not to be possible because there were too few regulations for which a cost-benefit analysis was performed. The following table gives the salient features of the two groups-regulations that were repealed and regulations for which CRA resolutions did not result in repeal. ${ }^{53}$ Note that we excluded independent agencies from these numbers; because they are not covered by the executive orders requiring OIRA review, cost-benefit analysis, or designation as unfunded mandates. Including them in the analysis would have potentially biased the results.

51. We intend to continue this research in a second phase in order to obtain a better grasp of the political dynamics involved in use of the CRA.

52. On December 12, 2018, the Senate passed a CRA resolution against a deregulatory action by the Trump Administration relating to campaign finance, which was expected to fail in the House. See Michelle Ye Hee Lee, Senate votes to overturn Trump administration donor disclosure rule for 'dark money' groups, WASH. POST (Dec. 12, 2018), https://www.washingtonpost.com/politics/senate-votesto-overturn-trump-administration-donor-disclosure-rule-for-dark-money-groups/2018/12/12/92d8d93afe3d-1 le8-ad40-cdfd0e0dd65a_story.html?utm_term=.386629a567cc [https://perma.cc/7QGJ-ZUVW]. This resolution was not included in the analysis.

53. Some cautions are in order. The final numbers may change since we are continuing to refine them. Also, cost-benefit information may have been available to Congress from sources other than the rules themselves, and we are continuing to examine those other information sources. 
Tables 2: Regulations by Non-Independent Agencies with CRA Resolution-Characteristics by Outcome ${ }^{54}$

\begin{tabular}{|l|l|l|l|l|l|l|}
\hline & $\begin{array}{l}\text { Percent } \\
\text { economi- } \\
\text { cally signif- } \\
\text { icant }\end{array}$ & $\begin{array}{l}\text { Percent } \\
\text { otherwise } \\
\text { designated } \\
\text { as } \\
\text { significant }\end{array}$ & $\begin{array}{l}\text { Percent } \\
\text { designated } \\
\text { as } \\
\text { unfunded } \\
\text { mandates }\end{array}$ & $\begin{array}{l}\text { Percent } \\
\text { with RIAs }\end{array}$ & $\begin{array}{l}\text { Percent } \\
\text { with } \\
\text { Relevant } \\
\text { Quantified } \\
\text { Benefits }\end{array}$ & $\begin{array}{l}\text { Percent } \\
\text { with } \\
\text { Relevant } \\
\text { Quantified } \\
\text { Costs }\end{array}$ \\
\hline $\begin{array}{l}\text { Repealed } \\
(\mathrm{N}=11)\end{array}$ & $18 \%(2)^{55}$ & $45 \%(5)$ & $0 \%(0)$ & $64 \%(7)$ & $36 \%(4)$ & $64 \%(7)$ \\
\hline $\begin{array}{l}\text { Not } \\
\text { repealed } \\
(\mathrm{N}=17)\end{array}$ & $29 \%(5)$ & $18 \%(3)$ & $12 \%(2)$ & $41 \%(7)$ & $35 \%(6)$ & $82 \%(14)$ \\
\hline $\begin{array}{l}\text { Total } \\
(\mathrm{N}=28)\end{array}$ & $25 \%(7)$ & $29 \%(8)$ & $7 \%(2)$ & $50 \%(14)$ & $36 \%(10)$ & $75 \%(21)$ \\
\hline
\end{tabular}

Many rules escaped Congressional review entirely. For instance, from July to December 2017, which was included in the period open to congressional review at the start of the Trump Administration, ${ }^{56}$ a search on reginfo.gov turns up forty-nine published final rules that were classified as economically significant. Yet the total number of economically significant rules reviewed by Congress in 2017 was only seven, around fourteen percent of the total number of regulations from non-independent agencies. One might have expected a larger number of CRA resolutions to be introduced, since doing so has no cost to a legislator and might please some local industry. This is one of many puzzles about the use of the CRA.

Perhaps most surprising was the lack of any apparent connection between cost and the outcome of the congressional review process: most of the high-cost regulations survived the process intact. Because only about a

54. There were CRA resolutions for eight regulations from independent agencies. This resulted in the repeal of five-a much higher percentage (62\%) as compared with regulations from executive agencies. This may have been due to the identity of the agencies involved or may simply have been due to chance, given the small numbers involved. Of the regulations repealed, two had quantified costs and none had quantified benefits. Of the regulations that were not repealed, two had quantified costs and one had quantified benefits.

55. This includes rules that did not explicitly state it was classified as significant on this basis or use the phrase "economically significant," but where we were able to confirm that the annual costs were over $\$ 100$ million.

56. See Michael Grunwald, Trump's Secret Weapon Against Obama's Legacy, PoLITICo (Apr. 10, 2017), https://www.politico.com/magazine/story/2017/04/donald-trump-obama-legacy-215009 [https://perma.cc/UB6G-GLEC] (Republicans had "until early May to eliminate Obama rules finalized after last June"). 
third of the regulations even had quantified benefits, asking questions about their cost-benefit ratios or net benefits would have involved small numbers, making a statistical analysis pointless. Regulations accompanied by a regulatory impact analysis (RIA) seemed to be less likely to survive congressional review.

If Congress had been concerned with the economic impact of regulations, we might have expected it to concentrate its attention on regulations with annual costs over $\$ 100$ million. It is also remarkable that one third of the regulations that attracted CRA resolutions were not considered significant by the agency or the White House. Either the Executive Branch was remarkably obtuse, or the features that attract congressional attention to a regulation are imperfectly understood by administrators. ${ }^{57}$ When the Administration did label a regulation as "otherwise significant," however, the odds that a CRA resolution succeeded did go up. Some of the regulations involved hot button issues for conservatives like guns or contraception. Others had impacted extractive industries that are close to the Republican party, notably the oil industry. ${ }^{58}$ The reasons for congressional opposition to other regulations are not obvious.

There is, in any event, little evidence that consideration of quantified costs and benefits played an important role in congressional decisionmaking. It may still be true that cost-benefit analysis did have salience to Congress in ways that we have not been able to observe. It is also possible that cost-benefit analysis normally exerts influence on Congress through channels such as committee hearings that are short-circuited by the CRA. Finally, the political atmosphere of the early Trump Administration may not reflect the normal operation of Congress. Thus, it would be premature to view our findings as disproving Cole's hypothesis that cost-benefit analysis influences Congress. At least, however, the findings clearly do not confirm this hypothesis. We see no clear indication that a regulation's net

57. These findings are consistent with the conclusions drawn in Case for Repeal:

Almost none of the rules that were repealed were all that controversial while they were under development. Among the rules eligible for repeal under the CRA, they did not impose the greatest costs on polluters or employers indifferent to unsafe working conditions; nor did the supporters of the repeal efforts attempt to make any credible case that they were an impediment to economic growth or job creation. Even Marc Short, President Trump's legislative affairs director, admitted as much, conceding at a White House briefing that "not each one of these [CRA repeals] can you look at and say it is necessarily a job creator."

Case for Repeal, supra note 45, at 7.

58. The group of cases in which CRA was invoked included one (the abolition of net neutrality) where the Democrats unsuccessfully attempted to overturn the regulation. 
benefits, nor even its total costs, were driving factors in the decision to overturn a regulation.

\section{REGULATORY REVIEW POLICIES AND OIRA'S ROLE}

We now turn from the possible use of regulatory analysis in the legislative branch to the executive branch. Almost immediately after taking office, Trump issued an executive order that imposed onerous new restrictions on agency rulemaking. ${ }^{59}$ If they remain in effect over the longterm, the requirements created in the executive order have the potential to transform the regulatory process. In the meantime, it is important to see whether OIRA's traditional role as reviewer of cost-benefit analysis has exercised any influence over deregulation, or whether in contrast ORA has simply rubberstamped deregulatory measures. In this section, the we examine this executive order and consider how OIRA has performed its role as overseer of the regulatory state since 2016.

\section{A. The "Two-for-One" Executive Order (EO 13771)}

Within the first two weeks in office, President Trump issued an executive order on regulatory reform. Executive Order 13771 contained two requirements. The first is the so-called two-for-one rule. Section 2(a) of the order provided that "whenever an executive department or agency (agency) publicly proposes for notice and comment or otherwise promulgates a new regulation, it shall identify at least two existing regulations to be repealed." Section 2(b) instructed agencies that "the total incremental cost of all new regulations, including repealed regulations, to be finalized this year shall be no greater than zero." Regarding future years, the OMB was charged with setting future regulatory budgets for agencies under section 3(d). Section 2(d) also charged OMB with issuing guidance to agencies. Finally, under section 4(a), these requirements do not apply to the government's "military, national security, or foreign affairs" functions.

This Executive Order is profoundly at odds with the core rationale of cost-benefit analysis. As Cass Sunstein has said, cost-benefit analysis would suggest quite a different approach:

For some agencies, the right approach might be "zero in, ten out," because there's no justification for anything new and a lot have to go. For other agencies, the right approach could be "ten in, zero-out," because all ten have benefits well exceeding costs, and there's really nothing to

59. Exec. Order No. 13,771, 82 Fed. Reg. 9339 (Jan. 30, 2017). 
eliminate. It follows that the right approach is not "one in, two out": but a careful check on issuing new rules, with the help of cost-benefit analysis-accompanied by an insistence on issuing those rules if the benefits justify the costs and an ambitious program for scrutinizing rules on the books to see if they should be scrapped. ${ }^{60}$

OIRA issued a guidance document clarifying some issues about the order. ${ }^{61}$ In terms of coverage, the Executive Order applies to significant rules and guidance documents (essentially meaning those subject to OIRA review anyway). ${ }^{62}$ The OIRA guidance also clarifies the definition of costs, indicating that the costs of a deregulatory action do not include all foregone financial benefits-for instance, if a regulation led to increased efficiency or reduced medical expenses, these constitute foregone benefits but not costs in terms of a deregulatory action. ${ }^{63}$ Thus, a deregulatory action could in fact impose large costs on society that would not be counted as such for purposes of the executive order. Alan Krupnick, a well-regarded environmental economist, has said that a fundamental problem with Trump's plan to reform regulatory rulemaking is that regulations can be eliminated that have larger benefits to society than costs because a regulation's possible net cost is only one of several alternative grounds for selecting regulations for repeal. ${ }^{64}$ Agencies must continue to use cost-benefit analysis, however, for all regulatory or deregulatory actions. ${ }^{65}$ Thus, at least in theory, any deregulatory action would have larger benefits than costs, or to put it another way, the regulation being repealed would have to have larger costs than bene-fits. However, in setting the deregulatory agenda of what rules to repeal

60. SUNSTEIN, supra note 49 , at 210 . Earlier, Sunstein says that he has a "decisive objection" to both the regulatory budget and the two-for-one requirement for these reasons. Id. at 20-21.

61. OfFICE of MOMT. \& BUdGeT, EXEC. OfFICE OF THE PRESIDENT, MEM. No. M-17-21, GUDANCE IMPLEMENTING EXECUTIVE ORDER 13771, TITLED "REDUCING REgulation AND CONTROLLING REGULATORY COSTS" (2017).

62. Id. at 3 .

63. Id. at 9 .

64. Alan J. Krupnick, Trump's Regulatory Reform Process: Analytical Hurdles and Missing Benefits, RESOURCES (Spring 2017), http://www.rff.org/research/publications/trump-s-regulatoryreform-process-analytical-hurdles-and-missing-benefits [https://perma.cc/RXS6-THZU]. Krupnick argues that, given the fact that previous regulations had to survive cost-benefit analysis to the extent consistent with law, "there will be few regulations with estimated benefits less than estimated costs," and many rules may involve the other factors in the executive order, so "there is no guarantee this benefit-cost criteria will be an effective check on eliminating rules with high net benefits." Id. Even if, contrary to Krupnick's analysis, agencies select only regulations with net costs to repeal, there is still a problem. Under the executive order, a regulation's net cost is not one of the factors to be considered in prioritizing regulatory repeals, only its gross cost (ignoring offsetting benefits). But it is the net cost of regulations that should be the key factor, because the net cost measures the extent of the rule's real burden on society. For instance, given two rules of equal cost, the agency should repeal the rule with smaller benefits, because that rule is more harmful to society.

65. Id. at 13 . 
the focus seems to be only on the cost of the repealed regulation, rather than on net benefits. In short, under the executive order, only costs are relevant in setting priorities; benefits are only relevant to the later issuance of a rule or its repeal.

The past two years have not provided a real opportunity to see how EO 13771 would actually constrain agencies. It does not appear that the EO 13771 currently imposes a genuine constraint on agencies, in that agencies are far exceeding their requirements. ${ }^{66}$ In Fiscal Year 2017, which included eight months of the Trump Administration, agencies issued sixty-seven deregulatory actions and only three regulatory actions, a 22:1 ratio. OIRA also reported that agencies saved $\$ 8.1$ billion in regulatory costs. For example, EPA completed sixteen deregulatory actions and only one regulatory action, for a net cost-savings of $\$ 571$ million. Roughly the same pattern seems to have persisted through September 2018, with many deregulatory actions. Thus, at present, Executive Order 13771 seems more significant in other respects: as a signal of the Administration's priority on deregulation; the Administration's intention to use of the number of regulations and total compliance cost as metrics; and an obstacle to any errant agencies seeking to engage in discretionary regulation actions.

The numerical, two-for-one portion of the order seems to be more of a public relations gesture than a serious effort at deregulation. Counting regulations is an arbitrary method of determining the scope of the regulatory state, since some regulations have large impacts while many may have minor significance. Jodi Short has provided a careful critique of arguments that the number of regulations has significant causal effects. ${ }^{67}$ As she shows, empirical studies based on regulation counts cannot cope with the diversity of regulatory provisions in scale and effect, not all of which are burdens on industry, and with definitional problems. ${ }^{68}$ Thus, we lack any strong reason to think that the sheer number of regulations is economically significant.

The FY 2017 ratio of twenty-two to one between deregulation over regulation cited above exemplifies some of the problems with bean counting. Apart from the fact that a third of the deregulatory actions actually

66. OFFICE OF INFO. \& REGULATORY AFFAIRS, REGULATORY REFORM: TWO-FOR-ONE STATUS REPORT AND REGULATORY COST CAPS-EXECUTIVE ORDER 13771: FINAL ACCOUNTING FOR FISCAL YEAR 2017 AND COST CAPS FOR FISCAL YEAR 2018 (2017), https:/www.reginfo.gov/public/pdf/ eo13771/FINAL_TOPLINE_All_20171207.pdf [https://perma.cc/7X27-JTXX].

67. Jodi L. Short, The Trouble With Counting: Cutting Through the Rhetoric of Red Tape Cutting, 103 MINN. L. REV. (forthcoming 2018).

68. Id. at 19-49. 
began under President Obama, a number of the others involved relatively inconsequential actions. It is far from clear that the number of regulations is a significant data point. ${ }^{69}$ As Professor Cary Coglianese put it, "It is not too much of an exaggeration to say that administrative officials are removing 22 'Peter Rabbit' books from the regulators' shelves for every one 'War and Peace' they add."70 The administration's 2018 regulatory agenda showed thirty-two deregulatory actions and twenty regulatory ones; the deregulatory actions include "allowing the importation of fresh pomelo fruit from Thailand and pine shoot beetle deregulation."71 The same pattern of few new regulations and many (often inconsequential) deregulatory actions seems to have persisted through September 2018, though much more important deregulatory actions are already underway. ${ }^{72}$ OIRA's Fall 2018 regulatory agenda stated that agencies had achieved $\$ 23$ billion in net regulatory cost savings across the government, issuing 176 deregulatory actions (including 57 significant deregulatory actions) and 14 significant regulatory actions. ${ }^{73}$ The complete FY2018 report claims $\$ 33$ billion in cost savings, with the bulk of the savings involved reporting and recordkeeping requirements by the Department of Health and Human Services. ${ }^{74}$ More than half of deregulatory actions produced no cost savings, and estimated cost savings were inflated because they did not take into account the lost benefits from the repealed rule. ${ }^{75}$ More generally, data-related rules (record-keeping, monitoring, and disclosure) may be especially appealing targets for repeal since compliance costs can be determined relatively easily but the benefits of such rules may be diffuse and unlikely to attract public scrutiny. ${ }^{76}$

69. Glenn Kessler, Has the Trump Administration Repealed 22 Regulations for Each New One?, WASH. POST (Aug. 3, 2018), https:/www.washingtonpost.com/news/fact-checker/wp/2018/08/03/hasthe-trump-administration-repealed-22-regulations-for-each-new-one/7utm_term=.acc41 fc84bdd [https:// perma.cc/ZRE8-BPHM].

70. Id.

71. Id.

72. Connor Raso, How has Trump's Deregulatory Order Worked in Practice?, BROOKINGS (Sept. 6, 2018), https://www.brookings.edu/research/how-has-trumps-deregulatory-order-worked-in-practice/ [https://perma.cc/5MF5-QZQS].

73. NEOMI RAO, INTRODUCTION TO THE FALL 2018 REGULATORY PLAN (2017), https:// www.reginfo.gov/public/jsp/eAgenda/StaticContent/201810/VPStatement.pdf [https://perma.cc/A2U72BFN].

74. Connor Raso, What does $\$ 33$ billion in regulatory cost savings really mean?, BROOKINGS (Jan. 10, 2019), https://www.brookings.edu/research/what-does-33-billion-in-regulatory-cost-savingsreally-mean/ [https://perma.ce/28WB-C652].

75. Id.

76. See ENVTl. Law InSt. \& Am. Bar Ass'N Section of Civil. Rights \& Soc. Justice, ENVIRONMENTAL PROTECTION IN THE TRUMP EPA ch. 2 (2018). 
The regulatory budget aspect of EO 13771 may be more significant than the two-for-one rule. ${ }^{77}$ The debate about regulatory budgeting has been underway for some time, and such measures in various forms have been used in other countries. ${ }^{78}$ Susan Dudley, a former OIRA head, argues that regulatory budgets may counter the incentives for agencies to overregulate and pad their estimates of regulatory benefits. ${ }^{79}$ Presumably, she does not consider OIRA's efforts to ensure objective cost-benefit analyses sufficient to counter this threat. ${ }^{80}$ But it would seem equally plausible that in deregulatory administrations the opposite incentive would apply, leading agencies to exaggerate costs and minimize estimates of benefits.

In short, a regulatory budget is an effective cure for OIRA's inability to police agency cost-benefit analyzes only under contestable assumptions about agency incentives and OIRA's information capacities. Indeed, if those assumptions are valid, it would seem to make more sense to abolish cost-benefit analysis entirely, impose a regulatory budget, and count on agencies to maximize societal benefits subject to their budget constraint. No one seems to be proposing this, which seems to suggest a lack of confidence in the argument made by Dudley and others.

Moreover, regulatory budgeting could result in an agency's inability to undertake actions with large net social benefits. The reason is that to do so, it must identify existing regulations with higher total costs. The pool of potential offsets is further limited because each of the repeals must also pass cost-benefit analysis. Thus, an agency could not rescind regulations

77. For a discussion of regulatory budgets and their implementation in the United Kingdom and two-for-one rules, see Jeffrey Rosen \& Brian Callanan, The Regulatory Budget Revisited, 66 ADMIN. L. REV. 835 (2014).

78. For a laudatory account of the Canadian experience by an author at a libertarian thinktank, see SEAN SPEER, REgUlatory BUDGETING: LESSONS FROM CANADA (R STREET POLICY STUDY No. 54) (2016), https://www.rstreet.org/wp-content/uploads/2016/03/RSTREET54.pdf [https://perma.cc/GS3J7SMN].

79. See Susan Dudley, Regulating Within a Budget, REG. REV. (Apr. 23, 2018), https:// www.theregreview.org/2018/04/23/dudley-regulating-within-a-budget/ [https://perma.cc/V52C-K7BZ]. For a discussion of the experience with regulatory budgeting in the United Kingdom, see BENJAMIN M. MILLER ET AL., INCHING TOWARD REFORM: TRUMP'S DEREGULATION AND ITS IMPLEMENTATION 9-10 (2017), https://www.rand.org/pubs/perspectives/PE241.html [https:/perma.cc/DR99-2GUN].

80. Similarly, an early advocate of regulatory budgets argued against including any consideration of regulatory benefits because "[a]gencies inevitably believe that all of their regulations confer net benefits. To remedy this, agencies subject to a budget would not be allowed to offset regulatory costs with benefits, since no regulation would fail to qualify under agencies' internal criteria." Clyde Crews Jr., Promise and Peril: Implementing a Regulatory Budget (Apr. 6, 1996) (manuscript at 7), https:// ssrn.com/abstract=2758788 [https://perma.cc/D6RY-DUQK]. Presumably, the theory is that OIRA cannot adequately police the agency's estimates of benefits, while it can more effectively do so for costs. But if this is correct, the right solution would seem to be to impose a regulatory budget and eliminate cost-benefit analysis, leaving it to the agency to use its own judgment (which OIRA can't supervise effectively anyway) to select the regulations that have the greatest benefits within that budget. 
with small net benefits in order to offset the compliance cost of a new regulation with much larger benefits. Unless the agency can find enough regulations with negative net benefits to use as cost offsets, it cannot adopt discretionary regulations with large public benefits under the executive order (at least not without obtaining a waiver from OIRA). Assuming that OIRA has been even partially effective in ensuring that projects have net social benefits, the pool of available regulations to repeal may be quite limited. RAND researchers conclude that "the new EO could easily remove more benefits of regulation than costs," particularly given its focus on deregulating as opposed to identifying more efficient ways to achieve regulatory goals. ${ }^{81}$ Thus, for the executive order to be effective, OIRA must either have performed its oversight role quite poorly in the past or costbenefit analyses, however well conducted, must be quite poor at forecasting actual costs and benefits. Otherwise, there would be only a small pool of regulations with costs exceeding benefits that would qualify as offsets.

Finally, an assessment of the costs and benefits of regulatory budgeting must include opportunity costs. As RAND researchers point out, implementation "will significantly increase the amount of effort $\mathrm{OMB}$ and regulating agencies must put toward monitoring regulatory costs," including costs of regulations not previously subject to regulatory review. ${ }^{82}$ Moreover, agencies will need to go through the rulemaking process for at least three times as many rules as they did previously: once for the rule they want to adopt, and at least twice for the rules they need to repeal. Given limited agency resources, the result will be that the agency will be able to issue fewer new regulations even if those regulations have net social benefits.

An assessment of the two-for-one and regulatory budget requirements seems hard to disentangle from assumptions about the operation of the regulatory state. The EO 13771 requirements make sense if (1) regulatory agencies are prone toward overregulation; (2) cost-benefit analysis and OIRA review have been relatively weak checks; (3) the pool of existing regulations with negative social value is relatively easy to identify; and (4) there are a limited number of potential new regulations with substantial net benefits. These seem to have been the assumption of Trump's first OIRA Administrator, who said "too often in the previous administration the benefits were exaggerated and the costs downplayed" and that "most agencies

81. MILLER, supra note 79 , at 13 .

82. Id. at 9. 
have lots of cost savings they can go after." 83 Notably, in the transcript of a discussion with her, variants of the word "cost" were used eighty times whereas the word "benefit" was used only forty-eight times, of which five were general references to cost-benefit analysis. These anti-regulatory assumptions are surely widespread among conservatives other than herself.

In principle, the questions listed above present empirical issues, but there is insufficient evidence to settle any of them clearly and perhaps may never be. It would require a massive investigation of past regulations to determine whether the past regulatory-review process was as seriously flawed as EO 13771 seems to presume, and there is little prospect that such a study will ever take place. Thus, anti-regulatory conservatives who are highly skeptical about the regulatory state will see the requirements of EO 13771 as beneficial based on their own assumptions. Those who do not share those assumptions will instead see them as roadblocks to beneficial regulatory actions.

This discussion of the effects of regulatory budgets remains highly theoretical under the Trump Administration. The operation of the offset and budgeting requirements is predicated on the issuance of new regulations, which are likely to be scarce in this Administration. Whether the Executive Order will be retained by later Presidents is unknowable, but its linkage with Trump may affect the politics of retaining it. That, of course, will depend on whether Trump proves to be the harbinger of the future of American government or instead sparks an effective counter movement.

\section{B. OIRA Jurisdiction and Operations}

A smaller, but still significant change, in White House review involved tax regulations. Under agreements dating to the Reagan and Bush Administrations, some tax regulations were exempt from the normal White House review process. ${ }^{84} \mathrm{~A}$ new memorandum of agreement (MOU) between OMB and Treasury modifies that exemption. ${ }^{85}$ It provides for OIRA review of treasury regulations under three circumstances. First, OIRA will

83. Neomi Rao, Adm'r, Office of Info. \& Regulatory Affairs, Address at the Brooking Institution: What's Next for Trump's Regulatory Agenda 6, 18 (Jan. 26, 2018), https://www.brookings.edu/wpcontent/uploads/2018/01/es_20180126_oira_transcript.pdf [https:/perma.cc/9ZF9-XEHF].

84. Press Release, U.S. Dep't of the Treasury, Treasury, OMB Update Tax Regulatory Review Process (Apr. 12, 2018).

85. Memorandum of Agreement between U.S. Dep't of the Treasury and Office of Mgmt. \& Budget on Review of Tax Regulations under Executive Order 12866 (Apr. 11, 2018), https:// home.treasury.gov/sites/default/files/2018-04/04-11\%20Signed\%20Treasury\%20OIRA\%20MOA.pdf [https://perma.cc/M334-NKB8]. 
review when regulations create "a serious inconsistency or otherwise interfere with an action taken or planned by another agency." 86 Second, regulations will be subject to review when they "raise novel legal or policy issues, such as by prescribing a rule of conduct backed by an assessable payment." 87 Finally, regulations will be subject to review if they have "an annual non-revenue effect on the economy of $\$ 100$ million or more, measured against a no-action baseline." 88

Although the Government Accountability Office had called for reconsideration of the OIRA exemption for tax regulations, ${ }^{89}$ the change was not easily adopted. The MOU was the result of a power struggle between the head of OMB and the Treasury Secretary. ${ }^{90}$ Other political actors were divided, with some favoring Treasury in order to obtain faster implementation of a major tax reform law, while some members of Congress were "rooting for Mr. Mulvaney's office to wield greater oversight of the tax law, in the hopes that it would push for the most lenient interpretations of regulations that enable the largest number of businesses to pay lower rates under the law."91 Former officials were concerned that OIRA review would invite greater involvement by White House political staff and provide another avenue for access by lobbyists. ${ }^{22}$

Early reports on implementation of the MOU indicated that OIRA has not yet rejected any proposed tax regulations; there have been "several back-and-forth exchanges," although Treasury has not disclosed what changes were made in response to the comments. ${ }^{93}$ Industry representatives have reported varied experiences in meeting with OIRA and Treasury officials, with one describing a silent, "stoic" audience, while "two other lobbyists, who attended separate meetings, said there was some dialogue between the industry representatives and the officials present, although they both noted it was almost exclusively OMB and OIRA staff who inter-

86. Id. at 1 .

87. Id.

88. Id.

89. See U.S. Gov't AcCOUNTABILITY OFFICE, GAO 16-720, TREASURY AND OMB NEED to REEVALUATE LONG-STANDING EXEMPTIONS OF TAX REGULATIONS AND GUIDANCE 35 (2016).

90. Alan Rappeport \& Jim Tankersley, White House Turf Battle Threatens to Delay Tax Law Rollout, N.Y. TIMES (Apr. 3, 2018), https:/www.nytimes.com/2018/04/03/us/politics/tax-lawregulations-omb-treasury.html [https://perma.cc/GZ7M-GNEG].

91. Id.

92. Id.

93. Jonathan Curry, Behind the Scenes at OMB: How's That New Agreement Working Out?, TAXNOTES (Sept. 11, 2018), https://www.taxnotes.com/editors-pick/behind-scenes-omb-hows-newagreement-working-out [https://perma.cc/KJU8-9CCE]. 
acted, rather than anyone from Treasury." 94 Other officials have also been involved: "a National Economic Council official attended two meetings on the highly anticipated section 199A passthrough deduction regulation, and a senior adviser with the Department of Housing and Urban Development was at a meeting about the regulations addressing state and local income tax deduction workaround strategies." 95 These lobbyists "indicated that with the deregulation-focused Trump administration in power, they view the meetings with the OMB, and the agency itself, as a potential backstop against tax [regulations] that may be damaging to their interests, based on the statutes or on prior statements by Treasury," and they added that they were pleased with the eventual regulations. ${ }^{96}$ It remains to be seen whether OIRA involvement will lead to improved regulation or whether the fears of the opponents of the change will be realized, with more political and special interest influence over regulations.

It is difficult to tease out the actual role played by OIRA in reviewing regulations because the process is so opaque. In particular, it is hard to be sure of the extent to which OIRA is acting as an honest economic broker as opposed to providing a channel for the President's agenda or special interests (perhaps via other agencies OIRA consults during the review process). David Barron suggested a decade ago that OMB may not be easily amenable to presidential influence, because it is a technocratic organization, largely staffed by civil servants, and dedicated to the goal of minimizing regulatory costs. ${ }^{97}$ More recently, Michael Livermore observed that the heads of OIRA under the Clinton, Bush, and Obama Administrations tended to exercise a moderating influence on administration policy, having "less of an ideological ax to grind than the median political appointee in their respective administrations."98 It is unclear whether Trump's first administrator, Neomi Rao, was able to play this role, or whether her successor will be able to do so.

One concern is about how OIRA sees its own role in terms of deregulation. In principle, it is just as important to assess the costs and benefits of proposed deregulations as for proposed regulations. In fact, in most in-

94. Id.

95. Id.

96. Id.

97. David J. Barron, From Takeover to Merger: Reforming Administrative Law in an Age of Agency Politicization, 76 GEO. WASH. L. REV. 1095, 1112-13 (2009).

98. Michael A. Livermore, Regulatory Impact Assessment in the Age of Partisan Volatility, REG. REV. (May 2, 2018), https://www.theregreview.org/2018/05/02/livermore-regulatory-impactassessment-age-partisan-volatility/ [https://perma.cc/ZS7W-ZCEV]. 
stances, a higher level of scrutiny would be justified because the target of repeal is itself a regulation that had survived OIRA scrutiny. But OIRA may not see its function that way, and it might also lack as much leverage over deregulatory actions. Neither of those conclusions would surprise OIRA's progressive critics, who have always seen cost-benefit analysis as a façade for justifying reductions in regulatory protections for the public.

Whatever the reason, it is unclear whether OIRA is functioning effectively as an objective economic overseer of deregulation. Assessment of OIRA's performance is difficult because some of its most important activities, such as consultation with agencies before regulations are even proposed, are non-public. Even aspects of OIRA's activities that are supposed to be public often are not disclosed. Thus, judgments about OIRA's policy impact must be based to some extent on surmises from the available clues.

On at least one occasion, OIRA was either cut out of the process or engaged in only extraordinarily cursory review. OIRA's website initially showed that EPA issued a proposed rule, which substantially limited the types of scientific evidence that it would consider in rulemakings, before OIRA had completed its review. ${ }^{99}$ After this discrepancy was publicized, OIRA revised the date of completion of the review to be earlier. ${ }^{100}$ According to the revised record, OIRA completed its review in only four days, but it appears that some significant changes were made in the proposed rule during that time. ${ }^{101}$ On another occasion, it took OIRA only three days to review a proposal to delay major regulations of methane emissions, leaving no time for input to OIRA from the public or other agencies. ${ }^{102}$ On average, however, OIRA took fifty-two days to review non-economically significant rules. ${ }^{103}$ Obviously, there was a serious lapse in the review process in some cases with truncated review, but it is difficult to know if this is a symptom of a broader problem.

99. Gena Reed, What Happened During the Hasty White House Review of EPA's Science Restriction Rule?, UNION OF CONCERNED SCIENTISTS (May 7, 2018), https://blog.ucsusa.org/genna-reed/ what-happened-during-the-hasty-white-house-review-of-epas-science-restriction-rule [perma.cc/ME4F2SJJ].

100. Id.

101. Id.

102. Niina Heikkinen, White House sped review of methane rule delay, E\&E NEWS (Nov. 1, 2018), https://www-eenews-net.greenwire/stories/1060104929/ [https://perma.cc/SK9F-HQWG]. On another methane-related action, the White House pressured EPA to favor industry interests. Jennifer A Dlouhy, White House Backed Big Oil Over EPA on Finding Methane Leaks, BLOOMBERG (Oct. 19, 2018), https:/www.bloomberg.com/news/articles/2018-10-19/white-house-backed-drillers-over-epa-onplugging-methane-leaks [https://perma.cc/U7JC-QH7C].

103. Reed, supra note 99. 
On another occasion, it appears that OIRA did its job appropriately but was overruled by White House political staff. The Labor Department proposed repealing an Obama Administration rule that limited pooling of tips by employers. The proposal would have allowed employers to participate in the pool, reducing the amount of tips ultimately paid to employees. Within the Department, political appointees forced staff to progressively lower estimates of the amount of diverted tips, which were originally estimated at billions of dollars, down to $\$ 640$ million. OIRA insisted that this amount be included in the analysis, but the head of OMB overruled it and allowed the Department to delete the estimate. ${ }^{104}$ In interviews, fifteen former Cabinet-level and White House officials said "in their senior-level government rulemaking experience, they [could not] recall a single instance in which OIRA was ordered to approve a regulation that [did not] include any form of quantitative analysis when OIRA knew such data was available." 105

Both of these incidents raise concerns about whether OIRA is in a position to ensure adequate analysis of proposals. At this point, however, we have no way of knowing whether these incidents were aberrations or symptoms of a larger pattern. ${ }^{106}$ There are, however, at least grounds for real concern about OIRA's ability to function professionally under Trump.

\section{Agency-Specific Modifications of Cost-Benefit Guidelines}

Two initiatives at EPA would modify its future use of cost-benefit analysis in a way inconsistent with OIRA's general guidelines for agencies. The fact that these initiatives are proceeding may be an indication of a loss of ability of OIRA to enforce its own guidelines against agencies. These initiatives are at odds with OIRA's announced "larger objective of analytical consistency in estimating benefits and costs across regulations and agencies, subject to statutory limitations." 107 Deviations from cross-agency

104. Ben Penn, Mulvaney, Acosta Override Regulatory Office to Hide Tips Rule Data, BLOOMBERG (Mar. 21, 2018), https:/www.bna.com/mulvaney-acosta-override-n57982090099/ [https:// perma.cc/55V6-M8J2]. Officials denied the reports, but those denials are contradicted by documentary evidence.

105. Id.

106. The Bloomberg story also reports that the "White House has also been suspected of overruling OIRA in clearing Environmental Protection Agency regulations that would erase Obama-era rules." Id. The story does not, however, provide any details.

107. OfFICE of MGMT. \& BUDGet, EXec. Office of THE President, CirCular A-4 8 -9 (2003), https:/www.whitehouse.gov/sites/whitehouse.gov/files/omb/circulars/A4/a-4.pdf [https://perma.cc/ CS22-Y34Z]. 
consistency, OIRA says, "may prevent achievement of the most risk reduction for a given level of resource expenditure."108

One of the EPA proposals presents itself as an effort to increase transparency in the use of scientific evidence. ${ }^{109}$ According to a leading scientific journal, however, "longtime observers of EPA, including former senior agency officials, see a more troubling and targeted goal: undermining key studies that have helped justify stricter limits on air pollution." 10 The proposed rule would require that for "the science pivotal to its significant regulatory actions, EPA will ensure that the data and models underlying the science is publicly available in a manner sufficient for validation and analysis." 111 As a footnote explains, this goal is to be accomplished by limiting the science that EPA can consider:

EPA has the authority to establish policies governing its reliance on science in the administration of its regulatory functions. Historically, EPA has not consistently observed the policies underlying this proposal, and courts have at times upheld EPA's use [of] non-public data in support of its regulatory actions....EPA is proposing to exercise its discretionary authority to establish a policy that would preclude it from using such data in future regulatory actions. 12

Because it could exclude important, well-validated studies if the underlying data could not be disclosed publicly, this limitation on the use of widely accepted research findings would be inconsistent with OIRA's injunction to agencies to "provide documentation that the analysis is based on the best reasonably obtainable scientific, technical, and economic information available." 113 At one point, vehement resistance to this proposal from the scientific community appeared to have had some effect, since the expected completion date of the rule was delayed until 2020 in EPA's regulatory budget. ${ }^{114}$ But more recently, the EPA Administrator announced that

108. Id. at 9 .

109. Strengthening Transparency in Regulatory Science, 83 Fed. Reg. 18,768 (Apr. 30, 2018).

110. Warren Comwall, Critics See Hidden Goal in EPA Data Access Rule, 360 SCIENCE 472 (2018).

111. Strengthening Transparency in Regulatory Science, 83 Fed. Reg. at 18,769 .

112. Id. at 18,769 n.3.

113. OFFICE OF MGMT. \& BUDGET, supra note 107 , at 17.

114. Abby Smith, EPA 'Secret Science' Rule May Not See Daylight Until 2020, BLOOMBERG (Oct. 17, 2018), https://www.bna.com/epa-secret-science-n73014483401/ [https://perma.cc/47JS-J2RG]. This proposed rule is part of a broader effort by the administration to reduce the role of science in the policy arena. Relevant developments regarding budgets, advisory board membership, rejection of widely accepted scientific findings and methodologies, and censorship of governments scientists are carefully documented in Albert Lin, President Trump's War on Regulatory Science, HaRV. ENVTL. L. REV. (forthcoming), https://papers.ssm.com/sol3/papers.cfm?abstract_id=3248058 [https://perma.cc/C324JVA8]. 
"[i]t is not a back-burner issue," and that "we will move forward to finalize that next year." 115 Thus, contrary to OIRA guidelines, EPA seems determined to adopt an exclusionary rule for probative scientific evidence in pursuit of its "transparency" goal.

Another EPA initiative would restrict consideration of regulatory benefits, excluding any benefits that are not directly related to the regulated pollutant. In an Advance Notice of Proposed Rulemaking, EPA requested comment on whether the agency should develop a rule to limit "how the Agency will weigh the benefits from reductions in pollutants that were not directly regulated (often called 'co-benefits' or 'ancillary benefits')." 16 Limiting the consideration of ancillary benefits would be inconsistent with OIRA guidance that requires agencies to identify the "ancillary benefits" of proposed regulations and add those to the direct benefits and costs. ${ }^{17}$ OIRA instructs agencies that "[y]our analysis should look beyond the direct benefits and direct costs of your rulemaking and consider any important ancillary benefits and countervailing risks." 118

These initiatives are significant even if they prove not to result in the issuance of final rules, because they indicate the decreasing grip of CBA as the standard for rational, data-driven decision making. If cost-benefit analysis is supposed to ensure that regulations are adopted when (and only when) they benefit society, excluding probative scientific evidence or a major category of regulatory benefits is totally inconsistent with that goal. The fact that these EPA rules are seemingly moving forward may also be a signal of decreasing influence by OIRA, given that these initiatives in such tension with OIRA's general guidance and its efforts to achieve uniformity across agencies have progressed as far as they have.

This survey of general policies regarding CBA provides only half the story. The other half involves the professionalism and integrity of the practice of CBA within the Administration. To get a better sense of how cost-

115. Timothy Cama, EPA to pursue final 'science transparency' rule in 2019, THE HILL (Dec. 14, 2018), https://thehill.com/policy/energy-environment/421479-epa-to-pursue-final-science-transparencyrule-in-2019 [https://perma.cc/9VKM-SFMP].

116. Increasing Consistency and Transparency in Considering Costs and Benefits in the Rulemaking Process, 83 Fed. Reg. 27,524 (June 13, 2018). Professor Michael Livermore, a leading advocate of cost-benefit analysis, refers to the rule's "purported purpose" of increasing consistency and transparency, while viewing "the likelihood of a reasoned, balanced, and legitimate approach to reforming costbenefit analysis at the agency seems so remote as to be almost unimaginable." Michael A. Livermore, Tainted Review, REG. REV. (Aug. 29, 2018), https:/www.theregreview.org/2018/08/29/livermoretainted-review/ [https://perma.cc/HE6Y-VCSE].

117. OFFICE OF MGMT. \& BUDGET, supra note 107, at 3 .

118. Id. 
benefit analysis is actually being implemented in the Trump Administration, the next section will consider several case studies. The case studies stem from an agency that has often been the subject of criticism by antiregulatory advocates, so it would appear to provide a good test case of the application of economic analysis to deregulatory actions.

\section{APPLICATION OF REGULATORY REVIEW AT EPA}

EPA has been a particular target of Republican ire and of the Trump Administration. As Richard Revesz points out, this targeting is not reflective of existing cost-benefit analyses of the agency's activities. Those analyses-including a report by OMB under the Trump Administration-have indicated that EPA's regulations have had large net benefits:

In its 2017 summary of the costs and benefits of all major federal regulations for which costs and benefits had been estimated, OMB reported aggregate benefits of between $\$ 287$ and $\$ 911$ billion and costs of only between $\$ 78$ and $\$ 115$ billion. Of these regulations, EPA rules account for over eighty percent of all monetized benefits- between $\$ 240$ and $\$ 784$ billion - and over seventy percent of all monetized costs-between $\$ 65$ and $\$ 85$ billion. ${ }^{119}$

EPA has also issued three studies of the costs and benefits of the Clean Air Act; an EPA study covering 1990 to 2020, forecasting that air pollution regulations would produce annual net benefits of $\$ 1.9$ trillion by 2020. ${ }^{120}$ Richard Revesz notes that these high net benefits are due to the large public health benefits of EPA rules, with a projected 230,000 lives saved annually by $2020 .^{121}$ This amounts to roughly two million lives saved in the decade from 2010-2020. ${ }^{122}$

Even if we were to assume that agencies systematically exaggerate benefits and underestimate costs despite OIRA oversight, it is not easy to devise a theory to explain why OIRA has been dramatically less successful in policing EPA than other agencies. If we assume that the extent of the distortions in CBA at EPA are comparable to other agencies, the implication would be that EPA is relatively benign, in terms of net societal impact, compared to other agencies. Thus, the targeting of EPA does not seem rea-

119. Richard L. Revesz, Congress and the Executive: Challenging the Anti-Regulatory Narrative 14-15 (N.Y.U. Sch. of Law, Pub. Law Research, Paper No. 18-42; N.Y.U. Law \& Econ. Research, Paper No. 18-32), https://papers.ssm.com/sol3/papers.cfm?abstract_id=3233933 [https://perma.cc/ UG83-WKTC].

120. Id.

121. Id. at 15 .

122. Id. at 15-16. 
sonable if the concern is the net impact of regulations on society. On the other hand, given the figures cited above, targeting EPA is entirely plausible if the concern is purely on regulatory costs (ignoring benefits).

\section{A. The Social Cost of Carbon}

Estimating the benefits of reducing carbon emissions is particularly difficult. Modeling the long-term economic impact of climate change and the costs of adaptation and mitigation involves tremendous challenges. ${ }^{123}$ According to the Congressional Research Service, "[1]ong-term projections ... should be viewed with skepticism.... The finer the detail, the greater the skepticism should be."124 Even the more confident economic modelers ${ }^{125}$ admit that attempts to estimate the impacts of climate change continue to be speculative. ${ }^{126}$ As discussed in Part I, over multiple-decadal time scales, a minor shift in the discount rate can dramatically impact the analysis of whether additional precautions are warranted. Given the very long-term effects of climate change, a small change in the discount rate can drive huge changes in the results. Yet, there is no consensus about what discount rate to use for climate change. ${ }^{127}$

In 2009 the Interagency Working Group on Social Cost of Carbon (IWG) was convened to reduce the agency cacophony and provide a uniform estimate. ${ }^{128}$ The process was convened by OMB and the Council of Economic Advisors. ${ }^{29}$ The other key participants were the agriculture,

123. For a good overview of modeling issues, see J.C. Hourcade et al., Estimating the Costs of Mitigating Greenhouse Gases, in CLIMATE CHANGE 1995: ECONOMIC AND SOCIAL DIMENSIONS OF Climate Change: WorkINg GROUP III CONTRIBUtIon to THE IPCC SECOND ASSESSMENT RePORT 268 (1996) (discussing the critical determinants likely to influence the overall cost of climate policies and of the main methodologies employed to account for them).

124. Darren Samuelsohn, Uncertain economic models create headaches for Senate panel, E\&E NEwS (Oct. 14, 2009), http://www.eenews.net/Greenwire/2009/10/14/archive/ 5?terms =Climate\%3A+Uncertain+Economic+Models+Create+Headaches+for+Senate+Panel [https:// perma.cc/4M56-F9K6].

125. WILLIAM D. NORDHAUS \& JOSEPH BOYER, WARMING THE WORLD: ECONOMIC MODELS OF GLOBAL WARMING (2000).

126. Id. at 86 (conditioning their model on the need for a "detailed inventory and valuation of climatically sensitive regions for validation").

127. For a concise overview of the relevant literature, see Kolstad \& Urama, supra note 36.

128. INTERAGENCY WORKING GRP. ON SOC. COST OF CARBON, TECHNICAL SUPPORT DOCUMENT - COST OF CARBON FOR REgULATORY IMPACT ANALYSIS- UNDER EXECUTIVE ORDER 128664 (2010), https://www.epa.gov/sites/production/files/2016-12/documents/scc_tsd_2010.pdf [https://perma.cc/QMF5-X3VP].

129. Id. at 3 . 
commerce, energy, transportation and treasury departments along with EPA. ${ }^{130}$

Rather than develop its own model, the government decided to three existing models of the impact of climate change of varying degrees. ${ }^{131}$ It chose those three models as being frequently cited in the peer review literature and by the IPCC. ${ }^{132}$ The IWG recognized the incomplete and very uncertain nature of the models. ${ }^{133}$ But given the lack of better data about the connection between climate and economic impacts, the group was unable to identify a superior approach short of launching its own expensive and time-consuming research program. ${ }^{134}$ In addition, the Interagency Working Group limited itself to determining the benefits from relatively small increments in emissions, so the results do not necessarily apply in considering the benefits of more drastic changes in emissions policy. ${ }^{135}$

One key issue about cost-benefit analysis in the climate context is the appropriateness of including international damages. The Interagency Working Group opted to include those damages because of the exceptional nature of the climate change problem. ${ }^{136}$ First, the IWG maintained, international damages must be included because of the global nature of climate change harms. Second, international cooperation is needed to address the issue. ${ }^{137}$ Moreover, the IWG argued in a separate subsection of its report, nearly all of the economics literature focused on global impacts, complicating any effort to derive a purely domestic estimate. ${ }^{138}$ The IWG also carefully considered the choice of discount rates. ${ }^{139}$ It concluded that a three percent rate was most defensible, but that reasonable arguments could be made for rates of $2.5 \%$ and $5 \% .{ }^{140}$ Hence, although the Interagency Working Group viewed the three percent discount rate as the norm, it emphasized the "importance and value of considering the full range." 141 The

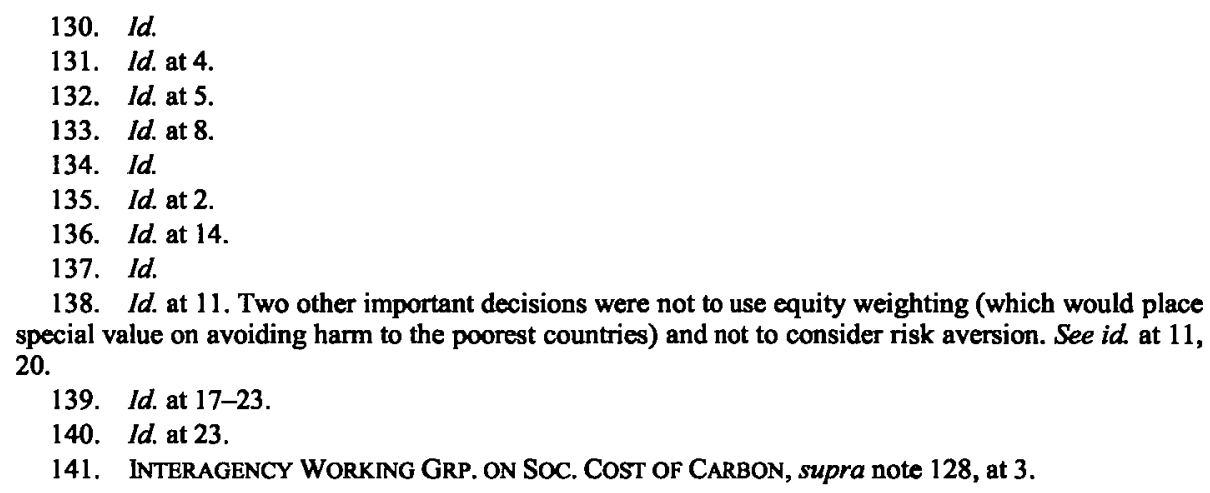

138. Id. at 11 . Two other important decisions were not to use equity weighting (which would place special value on avoiding harm to the poorest countries) and not to consider risk aversion. See id. at 11 ,

139. Id. at $17-23$.

140. Id. at 23.

141. INTERAGENCY WORKING GRP. ON SOC. COST OF CARBON, supra note 128, at 3. 20. 
IWG also believed it was useful to provide the cost corresponding to the ninety-fifth percentile of the model run estimates (at a three percent rate). This was intended to take into account the possibility of less likely but very damaging outcomes.

In Executive Order 13783, ${ }^{142}$ President Trump disbanded the Interagency Working Group and directed that individual agencies recalculate the social cost of carbon following general OIRA guidance on cost-benefit analysis "impacts and the consideration of appropriate discount rates." 143 The new calculation considers only the direct harm of climate change on the United States (not globally) and uses a relatively high discount rate, which results in giving serious long-term harms from climate change much less weight. Whether global impacts should be included in the social cost of carbon has been the subject of considerable scholarly discussion. ${ }^{144}$

Excluding global impacts is in tension with some internationallyoriented statutes bearing on the issue. First among these statutes is the National Environmental Policy Act (NEPA). Section 102(2)(F) of NEPA ${ }^{145}$ directs each agency of the federal government to "recognize the worldwide and long-range character of environmental problems and, where consistent with the foreign policy of the United States, lend appropriate support to initiatives, resolutions, and programs designed to maximize international cooperation in anticipating and preventing a decline in the quality of mankind's world environment." A second statute, section 115 of the Clean Air Act, ${ }^{146}$ requires EPA to take action whenever it "has reason to believe that any air pollutant or pollutants emitted in the United States cause or contribute to air pollution which may reasonably be anticipated to endanger public health or welfare in a foreign country." Although EPA is yet to take action under the specific authority of section 115 , this section indicates that global impacts were well within the scope of congressional concern. Finally, section 335 of the Defense Authorization Act of 2018 (H.R. 2810) ${ }^{147}$ states that it is the sense of Congress that "climate change is a direct threat to the national security of the United States and is impacting stability in areas of the world both where the United States Armed Forces are operating today, and where strategic implications for future conflict exist."

142. Exec. Order No. 13,783, 82 Fed. Reg. 16,093 (Mar. 28, 2017).

143. Exec. Order No. 13,783, § 5, 82 Fed. Reg. at 16,096.

144. Arden Rowell, Foreign Impacts and Climate Change, 39 HARV. ENVTL. L. REV. 371 (2015)

145. 42 U.S. C. $\S 4332(2)(F)(2012)$.

146. 41 U.S.C. $\$ 7415$ (2012).

147. Pub. L. No. 115-91, § 355, 131 Stat. 1283, 1358 (2017). 
Regardless of the arguments on both sides, Trump's executive order does not provide a rationale for ignoring global effects. As Cass Sunstein has said: "That decision may or may not be justifiable. But it was not justified. That is the height of arbitrariness." He adds that for this reason, the decision "should be invalidated in court." 148 Time will tell whether Sunstein's forecast about the legal outcome holds true. It is clear, in any event, that the choice to include only domestic damage is part of a larger trend in the Trump Administration of policy choices that truncate the consideration of regulatory benefits.

\section{B. Pollution Reduction Benefits}

A large share of the benefits from air pollution control comes from reducing the levels of particulates. ${ }^{149}$ Most of the benefits from reducing particulates are from reductions below the requirements of national air quality standards. ${ }^{150}$ As discussed in Part I, the Trump Administration is considering whether to eliminate these benefits from cost-benefit analysis of regulations that limit emissions of other pollutants but have the sideeffect of reducing particulates. Critics have also argued that reductions below air quality standards do not have public health benefits. ${ }^{151}$ The Trump Administration has accepted this argument in the regulatory impact analysis (RIA) for repealing the Clean Power Plan, President Obama's signature climate change regulation. ${ }^{152}$ The RIA for this proposal contains three estimates of particulate impacts, two of which assume that the health effects of particulates are zero below some threshold. That threshold is assumed to be either the lowest level at which health impacts have been found to date (in one estimate), or the air quality standard for particulates (in another). ${ }^{153}$ EPA has not generally treated particulates or other pollutants subject to national air quality standards as having a threshold for harmful effects and has frequently stated the contrary. ${ }^{154}$ Some critics of regulation argue that there is a threshold below which particulates have no

148. SUNSTEIN, supra note 49 , at 159.

149. Kimberly M. Castle \& Richard L. Revesz, Environmental Standards, Thresholds, and the Next Battleground of Climate Change Regulations, 103 MiNN. L. REV. (forthcoming 2019) (manuscript at 4), https://ssm.com/abstract=3154669 [https://perma.cc/JDW2-5PEA] (particulate reductions comprise the majority of air quality rule benefits).

150. Id. (manuscript at 4-5).

151. Id. (manuscript at 5).

152. Id. (manuscript at 6).

153. Id.

154. Id. (manuscript at 7). 
harmful effect. 155 Recent epidemiological studies, however, provide evidence of harmful effects below the current national standard for particulates, ${ }^{156}$ and even the Reagan Administration treated particulates as having no threshold below which they were harmless. ${ }^{157}$.

Eliminating consideration of co-benefits would reverse forty years of EPA practice. ${ }^{158}$ According to Kimberly Castle and Richard Revesz, "EPA has consistently and over multiple presidential administrations considered both co-benefits and their mirror image, indirect costs, in evaluating the consequences of regulation."159 The lower courts have consistently held that EPA must consider indirect costs. ${ }^{160}$ The D.C. Circuit has also upheld EPA's consideration of co-benefits. ${ }^{161}$ Most strikingly, in Michigan $v$. $E P A,{ }^{162}$ Justice Scalia's opinion for the Court emphatically admonished EPA to consider the full range of harms, direct and indirect, caused by regulation: "One would not say that it is even rational, never mind 'appropriate,' to impose billions of dollars in economic costs in return for a few dollars in health or environmental benefits. In addition, 'cost' includes more than the expense of complying with regulations; any disadvantage could be termed a cost," including environmental harms. ${ }^{163}$ The Trump Administration may have its work cut for it if it wants to persuade the courts that while "cost" including any disadvantage, "benefit" excludes important advantages. Indeed, the cost of repealing a regulation includes the lost benefits of the regulation, and Michigan v. EPA suggests that agencies must take a broad view of costs.

155. Id. (manuscript at 33 ).

156. Id. (manuscript at 39 ).

157. Id. (manuscript at 40 ).

158. Id. (manuscript at 9, 28-29). As Castle and Revesz explain, "[F]or all but one criteria pollutant [i.e., pollutant subject to national air quality standards], the agency has calculated benefits from alternatives more stringent than what EPA ultimately selected as its standard, and it has done so under presidents from both parties." Id. (manuscript at 28-29). They then survey EPA's historic practices for five pollutants, including EPA's consistent practice of performing such calculations and "its more explicit finding on the lack of evidence of thresholds." Id. (manuscript at 29).

159. Id. (manuscript at 51).

160. See Competitive Enter. Inst. v. Nat'l Highway Traffic Safety Admin., 956 F.2d 321, 323 (D.C. Cir. 1992); Corrosion Proof Fittings v. Envtl. Prot. Agency, 947 F.2d 1201, 1229-30 (5th Cir. 1991) (requiring consideration of harms caused by use of substitutes for asbestos in response to asbestos ban).

161. U.S. Sugar Corp. v. Envtl. Prot. Agency, 830 F.3d 579, 624-25 (D.C. Cir. 2016).

162. 135 S. Ct. 2699 (2015).

163. Id. at 2707 . 


\section{Cost-Benefit Analysis of Key Deregulatory Initiatives}

In this section, we examine how the Trump Administration has actually applied CBA in crucial administrative settings. It is impractical to cover every action taken by the Administration. Instead, we focus on three key deregulatory initiatives that rollback back Obama Administration initiatives to reduce carbon emissions from power plants, improve vehicle fuel efficiency (and thereby reduce carbon emissions), and protect wetlands.

\section{The Affordable Clean Energy (ACE) Rule}

The Clean Power Plan ${ }^{164}$ was the Obama Administration's most ambitious effort to reduce carbon emissions. ${ }^{165}$ Section 111(b) authorizes EPA to issue emission limitations for pollutants from new plants, and EPA did so for electric power plants. In order to regulate existing power plantsespecially existing coal-fired plants-EPA turned to section 111(d) of the Clean Air Act. ${ }^{166}$ Section 111(d) empowers EPA to require states to submit plans to control emissions from existing plants after it has issued a standard for new sources. The state plans are based on the "best system of continuous emission reduction" (BSER) that has been "adequately demonstrated" in terms of existing plants in that state. A crucial issue involved the scope of the term "system"- does it include only plant-specific emission reductions, or could a system be defined more broadly to include things like replacing coal with renewables?

The Obama Administration decided to define the "system" of electrical power generation broadly under section 111(d). In defining the best standard of performance, the Obama EPA considered emission reduction strategies that could be applied to the electricity grid, such as increased use of renewable energy by the same company to allow reduced use of its fossil fuel generators. Defining the system of pollution control to encompass changes in the amount of electricity introduced into the grid is a departure

164. Carbon Pollution Emission Guidelines for Existing Stationary Sources: Electric Utility Generating Units, 80 Fed. Reg. 64,661 (Dec. 22, 2015). For the history of EPA's involvement with climate change, see Jody Freeman \& David B. Spence, Old Statutes, New Problems, 163 U. PA. L. REV. 1, 1743 (2014).

165. For detailed descriptions of the Clean Power Plan, see Julie DeMeester \& Sarah Adair, EPA's Clean Power Plan: Understanding and Evaluating the Proposed Federal Plan and Model Rules, 45 ENVTL. L. REP. 11155 (2015); Gabriel Pacyniak, Making the Most of Cooperative Federalism: What the Clean Power Plan Has Already Achieved, 29 GEO. ENVTL. L. REV. 301 (2017).

166. 42 U.S.C. $\$ 7411$ (d) (2012). 
for EPA, which normally defines it as a type of pollution control equipment at the specific emitting facility 167

The RIA offers analyses of regulatory benefits with various options for interest rates. Using the IWG's preferred three-percent rate for carbon, the RIA found carbon reduction benefits of $\$ 25$ per ton in $2025 .{ }^{168}$ If a seven percent rate is applied to co-benefits, the total benefits for that year are $\$ 53-\$ 84,{ }^{169}$ meaning that the co-benefits are $\$ 28-\$ 59$ - either at least as much as the carbon benefits or as much as twice as large, depending on what parts of the ranges are used. With a smaller discount rate applied to health benefits, co-benefits loom even larger. ${ }^{170}$ Still, the carbon benefits were not an inconsiderable part of the total benefits. If we were instead to focus on the risk-averse, 95th percentile figures from the IWG, the carbon benefits went up dramatically, to $\$ 92$. The estimated compliance costs were much lower than any of these figures (in the range of $\$ 4-\$ 7$ per ton), ${ }^{171}$ so that the proposal would have been justified in terms of either carbon benefits alone or co-benefits alone. In order to justify repeal, the Trump EPA had to slash both the social cost of carbon and the co-benefits.

Besides rescinding the Obama-era estimate of the social cost of carbon, Executive Order 13783 directed EPA to reconsider the Clean Power Plan. ${ }^{172}$ EPA obediently issued a proposal to rescind the Clean Power Plan and replace it with a new, much weaker regulation, the Affordable Clean Energy (ACE) rule. ${ }^{173}$ In its proposal for repealing the Clean Power Plan,

167. For discussion of this issue, see Eric Anthony DeBellis, In Defense of the Clean Power Plan: Why Greenhouse Gas Regulation Under Clean Air Act Section 111(d) Need Not, and Should Not, Stop at the Fenceline, 42 ECOLOGY L.Q. 235 (2015).

168. U.S. ENVTL. PROT. AgENCY, REgUlatory IMPACT ANALYSIS FOR THE PROPOSED CARBON POLLUTION GUIDELINES FOR EXISTING POWER PLANTS AND EMISSION STANDARDS FOR MOdIFIED AND RECONSTRUCTED POWER PLANTS ES-18 (2014), http://www2.epa.gov/sites/production/files/2014-06/ documents/20140602ria-clean-power-plan.pdf [https://perma.cc/M877-KC7S] (Table ES-6). For simplicity, the discussion in the text focuses on the Option 1 portion of the table.

169. Id.

170. Id.

171. Id. at ES-21 (Table ES-8). EPA concluded:

The EPA could not monetize some important benefits of the guidelines. Unquantified benefits include climate benefits from reducing emissions of non- $\mathrm{CO}_{2}$ greenhouse gases and cobenefits from reducing exposure to $\mathrm{SO}_{2}, \mathrm{NO}_{x}$, and hazardous air pollutants (e.g., mercury and hydrogen chloride), as well as ecosystem effects and visibility impairment. Upon considering these limitations and uncertainties, it remains clear that the benefits of this proposal are substantial and far outweigh the costs.

Id. at ES-20.

172. Exec. Order No. 13,783, § 4, 82 Fed. Reg. 16,093, 16,095 (Mar. 28, 2017)

173. Emission Guidelines for Greenhouse Gas Emissions From Existing Electric Utility Generating Units; Revisions to Emission Guideline Implementing Regulations; Revisions to New Source Review Program, 83 Fed. Reg. 44,746 (Aug. 31, 2018). 
the Trump Administration adopted an industry argument that the Plan was invalid because EPA is limited to considering actions that can be implemented solely at an individual emissions source, such as installing new pollution control equipment. Recall that, in order to reduce carbon dioxide emissions, the Plan would require utilities to scale back electricity generation at coal-fired plants in favor of generators using natural gas or renewable sources. ${ }^{174}$ In other words, according to the Trump Administration, section 111 (d) is best read to authorize the agency to impose efficiency improvements for coal-fired plants but not to require that the electricity output of a coal-fired plants be reduced in favor of other sources of electricity.

Resources for the Future, a highly regarded economics-oriented think tank, published a careful analysis of the ACE approach in comparison with the Clean Power Plan's approach. ${ }^{175}$ The RFF economists concluded that at-the-source regulation like that in the ACE plan would result in a 2.6 percent decrease in carbon emissions compared with no regulation, while the Obama beyond-the-source approach would produce a thirty-six percent reduction. ${ }^{176}$ The ACE-type plan would also result in eighty-eight percent more sulfur dioxide emissions and fifty-six percent more nitrogen oxide emissions by 2030 , with correspondingly fewer public health benefits than the Obama plan. ${ }^{177}$

Given that the major projected benefits of the Clean Power Plan were to reduce carbon and particulate emissions, EPA's efforts to downgrade both benefits (as discussed in the previous section) would also support the argument for repealing the plan. ${ }^{178}$ Although this effect is buried in the Regulatory Impact Analysis (RIA), journalists quickly noticed that the plan would result in up to 1400 annual premature deaths due to particulates by

174. See Carbon Pollution Emission Guidelines for Existing Stationary Sources: Electric Utility Generating Units, 80 Fed. Reg. 64,662 (Oct. 23, 2015).

175. Amelia T. Keyes et al., Carbon Standards Examined: $A$ Comparison of At-the-Source and Beyond-the-Source Power Plant Carbon Standards (Resources for the Future, Working Paper No. 1820), http://www.rff.org/research/publications/carbon-standards-examined-comparison-source-andbeyond-source-power-plant [https://perma.cc/28N3-3T8M].

176. Id. at 3.

177. Id. at 11 .

178. On the other hand, several studies showed that compliance costs for the Clean Power Plan had fallen significantly due to other changes in the electricity sector. See DENISE A. GRAB \& JACK LIENKE, THE FALlING COST OF ClEAN POWER PLANT COMPLIANCE 17 (2017), https://policyintegrity.org/files/ publications/Falling_Cost_of_CPP_Compliance.pdf[https://perma.cc/T4DQ-7E6T]. 
2030, whereas the Clean Power Plan would reduce avoid annual 1,5003,600 premature deaths by that year. ${ }^{179}$

The cost-benefit information in the RIA is difficult to digest because it is contained in several tables, each of which discusses several alternative approaches. ${ }^{180}$ EPA was unsure of just how much individual plants would be able to improve their performance or of the cost of those improvements resulting in four implementation scenarios. ${ }^{181}$ The RIA notes that each scenario yielded "forgone climate benefits and forgone ancillary health cobenefits relative to the base case, which includes the CPP." 182 As directed by Trump's executive order, EPA followed the OIRA guidance for discount rates (three percent and seven percent) and used domestic benefits rather than international ones. ${ }^{183}$ The RIA responds to neither the arguments made by the IWG for considering lower discount rates or nor its reasons for including a risk averse estimate, nor its argument for using a global valuation of climate impacts. ${ }^{184}$ In terms of the evaluation of health risks, the RIA reports on the full range of concentrations and also on results assuming cut-offs such as eliminating any health effects below the national air quality standards. However, the RIA says it includes these cut-off estimates only as an indication of uncertainties at lower concentrations but that it primarily relies on the full-range estimates. ${ }^{185}$ Thus, the main reason for the much lower estimates of the Clean Power Plan's benefits, compared to those calculated under Obama, is that climate impacts have been drastically reduced by the shift to domestic estimates. ${ }^{186}$

179. Lisa Friedman, Cost of New E.P.A. Coal Rules: Up to 1,400 More Deaths a Year, N.Y. TIMES (Aug. 21, 2018), https://www.nytimes.com/2018/08/21/climate/epa-coal-pollution-deaths.html [https:// perma.cc/DEW6-3S2R].

180. U.S. ENVTL. PROT. AGENCY, REgULATORY IMPACT ANALYSIS FOR THE PROPOSED EMISSION GUIDELINES FOR GREENHOUSE GAS EMISSIONS FROM EXISTING ELECTRIC UTILITY GENERATING UNITS; ReVISIONS TO EMISSION GUIDELINE IMPLEMENTING REgUlationS; REVISIONS TO NEW SOURCE REVIEW PROGRAM 4-4 to 4-40 (2018), https://www.epa.gov/sites/production/files/2018-08/ documents/utilities_ria_proposed_ace_2018-08.pdf [https://perma_cc/F8JD-7XFD].

181. Id. at 1-7 to 1-8.

182. Id. at ES-12.

183. Id. at 4-3.

184. EPA was able to derive domestic estimates directly from two of the three models used by the IWG; for the third model, it approximated domestic impacts as ten percent of global impacts. Id. at 7-1. The RIA does point out that a report from the National Academies "discussed the challenges in developing domestic SC-CO2 estimates, noting that current integrated assessment models (IAMs) do not model all relevant regional interactions-i.e., how climate change impacts in other regions of the world could affect the United States, through pathways such as global migration, economic destabilization, and political destabilization." Id. at 4-6.

185. Id. at 4-26 to 4-27.

186. This also seems to be true of another climate-related initiative, repeal of an Obama Adminiștration rule limiting methane emissions from oil and gas production on public lands. See Alan $\mathrm{J}$. 


\section{Fuel Efficiency Standards: The SAFE Rule}

Another major Trump Administration initiative is the attempt to freeze fuel efficiency standards for vehicles. Section 202 of the Clean Air Act requires EPA to impose standards for emissions from new motor vehicles once it has found that a pollutant endangers human health or welfare. ${ }^{187}$ During the Obama Administration, EPA issued such standards for greenhouse gases, in tandem with the National Highway Traffic Administration (NHTSA), which regulates fuel efficiency standards for vehicles. ${ }^{188}$ The car industry was already under pressure because of regulations adopted in California, so the agencies were not writing on a blank slate. ${ }^{189}$ Those federal standards were scheduled to become increasingly strict for the next several years. The Administration proposed freezing the standards at their current levels. ${ }^{190}$ Such a regulatory freeze could cause problems for car manufacturers because California has its own standards for vehicle carbon emissions. ${ }^{191}$ Consequently, the manufacturers opposed freezing the standard and urged the Administration to negotiate a compromise with California. ${ }^{192}$

Krupnick \& Isabel Echarte, Does Repealing BLM's 2016 Methane Rule Pass a Cost-Benefit Test?, RESOURCES (Spring 2018), http:/www.rff.org/research/publications/does-repealing-blm-s-2016methane-rule-pass-cost-benefit-test [https:/perma.cc/Y4L9-4YE3].

187. 42 U.S.C. $\$ 7521$ (2012). Subsection (a) provides:

The Administrator shall by regulation prescribe (and from time to time revise) in accordance with the provisions of this section, standards applicable to the emission of any air pollutant from any class or classes of new motor vehicles or new motor vehicle engines, which in his judgment cause, or contribute to, air pollution which may reasonably be anticipated to endanger public health or welfare.

188. Freeman and Spence explain:

This first rule regulating GHGs under the CAA was novel, taking the form of a joint rulemaking that harmonized the two agencies' standards and created a uniform compliance program. The rule was especially notable because it gamered the support of the entire auto industry, which pledged not to challenge it if the final version substantially conformed to the agencies' initial proposal. Importantly, the new rule rendered GHGs a "regulated pollutant" under the CAA for the first time, which in turn tripped another wire in the statute requiring the agency to set standards for GHG emissions from stationary sources as well.

Freeman \& Spence, supra note 164, at 22.

189. For background on the negotiating process behind the issuance of the regulations, see Jody Freeman, The Obama Administration's National Auto Policy: Lessons From the 'Car Deal', 35 HARV. ENVTL. L. REV. 344 (2011).

190. Coral Davenport \& Hiroko Tabuchi, E.P.A. Prepares to Roll Back Rules Requiring Cars to Be Cleaner and More Efficient, N.Y. TIMES (Mar. 29, 2018), https:/www.nytimes.com/2018/03/29/ climate/epa-cafe-auto-pollution-rollback.html [https://perma.cc/FMX6-6SUY].

191. Id.

192. David Shepardson, Major automakers urge Trump not to freeze fuel economy targets, REUTERS (May 7, 2018), https://www.autoblog.com/2018/05/07/automakers-trump-cafe-standards-fueleconomy/ [https://perma.cc/8TLE-674T]. 
EPA and NHTSA eschewed compromise and took a different approach in its proposed SAFE rule. ${ }^{193}$ They not only proposed freezing the national standards but also proposed to preempt California's standards. ${ }^{194}$ The agencies estimated that costs would decrease by $\$ 502$ billion at a three-percent discount rate ( $\$ 335$ billion at a seven-percent discount rate), while benefits would decrease by $\$ 326$ billion, as compared with implementing the Obama-era rule. ${ }^{195}$ Industry remained unenthusiastic. The head of one major car company announced that "Ford is leading in this regard. ... We're in favor of keeping the standard, not a rollback. We have plans to meet it." 196

The Washington Post reported that "[s]taffers at the Environmental Protection Agency strongly criticized the logic behind a recent move to loosen future gas mileage rules for cars, at one point requesting that the EPA's name and logo be removed from a key regulatory report."197 According to the Post, while NHTSA claimed that freezing the standards would save lives, "EPA's internal analysis suggested the oppositethat freezing the Obama-era rules would lead to slightly more fatalities (seven for every trillion miles driven), cost jobs, and in economic terms, have a net negative impact of $\$ 83$ billion." 198 EPA staff notified OIRA of its technical disagreement and said the draft Regulatory Impact Statement should not be attributed to EPA; as far as we can tell from the public record, they were ignored by OIRA. ${ }^{199}$ It is possible, however, that OIRA did raise these concerns but was overruled.

Be that as it may, the proposal's RIA has also come under fire from economists outside the agency. The RIA relies on NHTSA models to project effects on fuel use, vehicle miles traveled, and accident rates for new and used vehicles. ${ }^{200}$ The direct benefits of fuel efficiency, in this analysis,

193. The Safer Affordable Fuel-Efficient (SAFE) Vehicles Rule for Model Years 2021--2026 Passenger Cars and Light Trucks, 83 Fed. Reg. 42,986 (Aug. 24, 2018).

194. Id. at $42,999-42,300$.

195. Id. at 42,998 .

196. Maxine Joselow, 'We're in favor of keeping the standard'-Ford CEO, E\&E NEWS (Sept. 21, 2018), www.eenews.net/greenwire/stories/1060099255 [https:/perma.cc/UMC2-Z9FZ].

197. Chris Mooney \& Dino Grandoni, The Trump administration said weaker fuel standards would save lives. EPA experts disagree., WASH. POST (Aug. 15, 2018), https:// www.washingtonpost.com/energy-environment/2018/08/15/trump-administration-said-weaker-fuelstandards-would-save-lives-epa-experts-disagree/?utm_term=.ed85091 fc8fc [https://perma.cc/HTR4DBC4].

198. Id.

199. Id.

200. See Alan J. Krupnick et al., Questions about the Trump Administration's Cost-Benefit Analysis for its Proposal to Freeze the CAFE Standards, RESOURCES FOR THE FUTURE (Aug. 20, 2018), http:/ 
are countered by the higher cost of new cars (which leaves more older, less efficient cars on the road), by higher accident rates (due to smaller, lighter cars), and by an increase in the number of miles driven. ${ }^{201}$ But the RIA appears to be internally inconsistent in its treatment of these issues, according to independent economists. Moreover, it appears, traffic safety experts sharply dispute the large reductions in deaths projected from the SAFE rule. ${ }^{202}$

RFF analysts faulted the RIA for assuming that the overall number of vehicles falls with the regulatory freeze despite lower prices for new vehicles. ${ }^{203}$ They said that "[o]n its face, this is inconsistent with economics."204 Moreover, the RIA assumes that at the same time that there are fewer vehicles, and that there will be more miles driven, which again seems inconsistent and "inconsistent with economics." 205 These dubious assumptions "are key because they result in significant reductions in external costs (such as congestion) and increases in safety from the change in vehicle ages and decreased driving under the proposed new rule." 206 Finally, the RFF ana-

/www.rff.org/blog/2018/questions-about-trump-administration-s-cost-benefit-analysis-its-proposalfreeze-cafe [https://perma.cc/9ECA-5TZU].

201. The reasoning behind the proposal has been summarized as follows by Brookings researchers:

This administration argues that freezing standards would improve safety by: (A) reducing the incentive for manufacturers' to deploy mass reduction technologies as a means to save fuel, claiming that on balance heavier vehicles are safer; (B) limiting the ripple effects of fuel savings, known as the "rebound effect," wherein consumers drive more because efficient vehicles are cheaper to operate, resulting in more vehicle miles traveled and more crashes; and (C) encouraging more drivers to buy [safer] new cars that would cost less.

Jason S. Miller \& Shoshana Lew Friday, The Trump administration's fuel-efficiency proposal is unnecessary and harmful, BROOKINGS (Aug. 3, 2018), https://www.brookings.edu/blog/the-avenue/2018/08/ 03/the-trump-administrations-fuel-efficiency-proposal-is-unnecessary-and-harmful/ [https://perma.cc/ XVJ4-4MJX].

202. Tom Krisher \& Ellen Knickmeyer, Lower fuel economy standards will save lives, Trump administration says, FoX NEws (Aug. 1, 2018), www.foxnews.com/auto/2018/08/01/lower-fueleconomy-standards-will-save-lives-trump-administration-says.html [https://perma.cc/PDA9-4K2H].

203. Alan J. Krupnick et al., supra note 200.

204. Id.

205. Jd.

206. Id. RFF economists also struggled to understand why the 2018 RIA showed much smaller reductions in fuel use from tighter standard:

[W] hy are estimated fuel cost savings in 2018 half what they were in $2016 ?$ As far as we can tell, the answer must be the on-road vehicle fleet. ... [T] he agencies argue that the on-road fleet is smaller when standards are weakened than when standards are tightened. The smaller fleet reduces the fuel cost savings from tighter standards, and it appears that this effect explains almost the entire reduction in fuel cost savings between the 2016 and 2018 analyses. But as we argued last week, there is good reason to suspect that the agencies are underestimating the fuel consumption and fuel costs if standards are weakened because they do not account for the increase in driving of vehicles that aren't scrapped. 
lysts concluded that assumptions about vehicle use and fuel consumption played a major role in the proposed rule and were based on assumptions about consumer behavior that were not supported by the economic literature. 207

Similarly, Berkeley economist James Sallee critiqued the economic analysis for "trying to have its cake and eat it too by claiming tighter standards will force consumers to buy less desirable cars, but they will still want to drive them more." $208 \mathrm{He}$ also criticized the report for ignoring the effect of the more expensive cars required by the Obama rule on depreciation costs, which makes it more expensive to pile-on mileage, and he concludes that EPA's aggressive estimates for the rebound effect do not pair well with its assumption about driving. ${ }^{209}$

Even the economists whose work the government relied on have denounced the cost-benefit analysis. In a December 2018 article in the journal Science, they concluded that "[ $\mathrm{t}]$ he 2018 analysis has fundamental flaws and inconsistencies, is at odds with basic economic theory and empirical studies, is misleading, and does not improve estimates of costs and benefits of fuel economy standards beyond those in the 2016 analysis." 210 Like other outside economists, they suggest that part of the Administration's analysis flunks Economics 101:

Justine Huetteman \& Joshua Linn, The Case of the Disappearing Fuel Cost Saving, RESOURCES FOR THE FUTURE (Sept. 24, 2018), http://www.rff.org/blog/2018/case-disappearing-fuel-cost-savings [https:/ /perma.cc/9GH3-7HPB].

207. See Joshua Linn, Missing Fuel Cost Savings: Some Clues Emerge, RESOURCES FOR THE FUTURE (Oct. 9, 2018), http://www.rff.org/blog/2018/missing-fuel-cost-savings-some-clues-emerge [https://perma.cc/HB26-AVLF].

208. James Sallee, Rebound's Role in Trump's Fuel Economy Rollback, ENERGY INST. (Sept. 8, 2018), https://energyathaas.wordpress.com/2018/09/08/rebounds-role-in-trumps-fuel-economyrollback/ [https://perma.cc/TMT9-4UHJ].

209. Id. The SAFE rule's cost-benefit analysis is also critiqued in BETHANY DAVIS NOLL ET AL., ANALYZING EPA'S VEHICLE-EMISSIONS DECISIONS: WHY WITHDRAWING THE 2022-2025 STANDARDS IS ECONOMICALLY FLAWED (May 2018), https:/policyintegrity.org/publications/detail/analyzing-epasfuel-efficiency-decisions1 [https://perma.cc/5NDT-QX3P]. For a detailed analysis of the economic issues, see Sylwia Bialek et al., Comments on The Safer Affordable Fuel-Efficient (SAFE) Vehicles Rule for Model Years 2021-2026 Passenger Cars and Light Trucks (Oct. 26, 2018), https:// policyintegrity.org/documents/Emissions_Standards_EPA_NHTSA_Comments_Oct2018.pdf [https:// perma.cc/FAF6-N3N5]. RFF also filed detailed comments, arguing among other things that "[c]orrecting the underlying behavioral assumptions dramatically raises fuel costs and traffic accidents for the weaker standards, cutting the net benefits of the proposed standards roughly in half, perhaps more." Joshua Linn et al., Comments to NHTSA and US EPA on the Safer Affordable Fuel-Efficient (SAFE) Vehicles Rule for Model Years 2021-2026: Passenger Cars and Light Trucks (Oct. 25, 2018), http://www.rff.org/files/document/file/Comments_10-25-18_EPA-NHTSA_final.pdf [http://perma.cc/ FJ4H-55XE].

210. Antonio M. Bento et al., Flawed Analyses of U.S. Auto Fuel Economy Standards, 362 SCIENCE 1119 (2018). 
The 2018 proposal argues that the rollback in standards will shrink the overall fleet by 6 million vehicles in the year 2029, compared with the current standards. This is inconsistent with basic economic principles. If prices of vehicles decrease (relative to other general-purpose goods), we expect more individuals to purchase vehicles and drive them rather than use other modes of travel. ${ }^{211}$

Of the three proposed rules studied, the cost-benefit analysis for the CAFÉ rollback seems clearly the weakest. The other two have their problems, but at least seem to be internally consistent. If it is true that EPA pushed back against the proposed freeze, that would seem to speak well for Administrator Wheeler, given that the proposal is so deeply flawed.

\section{Wetland and Stream Protection}

The final case study turns from air emissions to waterways, dealing with the fundamental question of what waters are covered by the federal statute regulating pollution and filling of waters. The Clean Water Act applies to "navigable waters," which are defined by section $502(7)$ as the "waters of the United States." 212 It is clear that at the very least the term includes what were traditionally called navigable waters, meaning bodies of water that could be used commercially for transportation. The difficulty has come from defining the boundaries of federal authority over small waterbodies and wetlands. The Supreme Court has decided three cases concerning this issue. The first two were relatively clear, but the third decision has caused great confusion. In the first case, United States $v$. Riverside Bayview Home, Inc., ${ }^{213}$ the Court held that wetlands adjacent to navigable waters were subject to federal jurisdiction. In the second case, Solid Waste Agency of Northern Cook County [SWANCC] v. U.S. Army Corps of Engineers, ${ }^{214}$ the Court struck down a regulation that made all bodies of water subject to federal jurisdiction if they are used by migratory birds. The case involved a small isolated body of water that was not connected even indirectly with navigable waters.

That brings us to the third case, Rapanos $v$. United States. ${ }^{215}$ Rapanos involved an area that was sometimes saturated with water, having previous-

211. Id. at 1120. An additional critique of the proposed rollback is that the agencies greatly overestimated its impact on new car sales. See Benjamin Leard, The Effect of Fuel Economy Standards on New Vehicle Sales, RESOURCES FOR THE FUTURE (Jan. 30, 2019), http:/www.rff.org/blog/2019/effectfuel-economy-standards-new-vehicle-sales [https:/perma.cc/M7JV-3M7A] (citing research papers).

212. 33 U.S.C. $\$ 1362(7)$ (2012).

213. 474 U.S. 121 (1985).

214. 531 U.S. $159(2001)$.

215. 547 U.S. 715 (2006). 
ly been a wetland before it was filled. The nearest body of traditionally defined navigable water was at least ten miles away. Four Justices voted to uphold the federal government's claim of jurisdiction, but they were in the minority. Another four Justices, led by Justice Scalia, defined federal authority narrowly, to include only open bodies of water such as continuously flowing streams and only adjoining wetlands that do not have a clear boundary from those open bodies of water. Justice Kennedy provided the fifth vote for the majority. He rejected the Scalia test. Instead, he said, to have authority over a wetland, the government must show a substantial nexus between that wetland and a tributary of a navigable body of water. (For instance, the wetland might store water that ultimately goes into the tributary). The decision caused confusion in the lower courts, with many lower courts viewing Kennedy's approach as legally binding and no court relying solely on Scalia's view. ${ }^{216}$

In an effort to provide additional clarity, the Army Corps of Engineers and EPA jointly issued the Waters of the United States guidance document, often called WOTUS for short. ${ }^{217}$ It was unclear whether the trial courts or the appeals courts had jurisdiction over the rule, so challengers to WOTUS filed suits at both levels. One court of appeals issued a nationwide injunction against enforcing WOTUS. But the Supreme Court ruled that only the trial courts have jurisdiction and reversed the injunction. ${ }^{218}$ While all this was happening, Trump took office.

As with the other regulations we have considered, President Trump once again initiated the repeal process. His executive order has the expansive title, "Presidential Executive Order on Restoring the Rule of Law, Federalism, and Economic Growth by Reviewing the 'Waters of the United States Rule."'219 The executive order also directs consideration of replacing the rule with Justice Scalia's very restrictive definition from Rapanos. ${ }^{220}$ EPA and the Army Corps gave notice of their intent to repeal WOTUS and

216. See N. Cal. River Watch v. City of Healdsburg, 496 F.3d 993, 1000 (9th Cir. 2007); United States v. Gerke Excavating, Inc. 404 F.3d 723 (7th Cir. 2006); United States v. Johnson, 467 F.3d 56, 60 (1 st Cir. 2006) (jurisdiction can be established under either the Kennedy or Scalia tests); United States v. Bailey, 571 F.3d 791, 799 (8th Cir. 2009) (same test as Johnson). The Fifth and Sixth Circuits have adopted their own approaches or dodged the issue. United States v. Lucas, 516 F.3d 316, 327 (5th Cir. 2008); United States v. Cundiff, 555 F.3d 200, 210-13 (6th Cir. 2009).

217. Clean Water Rule: Definition of "Waters of the United States", 80 Fed. Reg. 37,053 (June 29, 2015).

218. Nat'l Ass'n of Mfrs. v. Dep't of Def., 138 S. Ct. 617 (2018).

219. 82 Fed. Reg. 12,497 (Feb. 28, 2017). Section 2 of the executive order calls for reconsideration of WOTUS.

220. Id. $\S 3$. 
replace it with prior administrative practice until a replacement rule can be formulated.221

The agencies' advance notice of proposed rulemaking specifically stated that it did not rely on the cost-benefit analysis as a basis for the rule. ${ }^{222}$ This was a somewhat surprising deviation from the general norm, established in a series of executive orders, of maximizing net social benefits from regulatory decisions to the extent permitted by statute. ${ }^{223}$ In any event, the cost-benefit analysis came under serious criticism. In an article in Science, three environmental economists (two of them well-known senior figures) faulted the analysis for eliminating ninety percent of the estimated benefits projected under WOTUS. They said they could find "no defensible or consistent basis for decision to exclude what amounts to the largest category of benefits from the 2017 RIA," those benefits being the intrinsic value of wetlands based on contingent valuation studies. ${ }^{224}$ The 2017 RIA excluded the critical contingent valuation studies based on their age, but was not consistent in applying this age-based exclusion elsewhere in the report, nor did the RIA provide reasons for thinking that the results were no longer valid. ${ }^{225}$ Moreover, the RIA ignored ten more recent studies. ${ }^{226}$

The proposed rule 227 was published in December 2018 just before completion of this article. Unlike Justice Scalia's Rapanos opinion, which it follows only in part, the proposal does not contend that its interpretation is unambiguously required by the statute, only that the agencies "are proposing outer bounds for their authority under the Act that they consider objective and reasonable, and that are consistent with its text, structure,

221. Definition of "Waters of the United States"-Recodification of Preexisting Rule, 83 Fed. Reg. 32,227 (July 7, 2017).

222. The rule states: "While economic analyses are informative in the rulemaking context, the agencies are not relying on the economic analysis performed pursuant to Executive Orders 12866 and 13563 and related procedural requirements as a basis for this proposed action." $I d$. at 32,250 . This may be an effort to avoid judicial review of the cost-benefit analysis, since the next sentence reads: "See, e.g., NAHB, 682 F.3d at 1039-40 (noting that the quality of an agency's economic analysis can be tested under the APA if the 'agency decides to rely on a cost-benefit analysis as part of its rulemaking')." Id.

223. See supra Part I for a discussion of these orders.

224. Kevin J. Boule et al, Deciphering dueling analyses of clean water regulations, 358 SCIENCE 49, 49 (2017).

225. Id. at 50.

226. Id.

227. DEP'T OF DEF. \& U.S. ENVTL. PROT. AGENCY, REVISEd DEFINITION OF “WATERS OF THE UNITED STATES" (2018), https:/www.epa.gov/sites/production/files/2018-12/documents/wotus_2040af75_nprm_frn_2018-12-11_prepublication2_1.pdf [https://perma.cc/MRL3-YJ7F] (prepublication copy). 
legislative history and applicable Supreme Court precedent."228 The actual effects of the proposal remain unclear; a news report on the proposal had the apt title, "Trump Waters Proposal Narrower with Impact Clear as Mud."229

The cost-benefit analysis accompanying the proposal ${ }^{230}$ provides only an incomplete assessment of lost regulatory benefits. The agencies professed to be unable to determine the number of wetlands that would be affected by paring back not only the WOTUS rule but also the pre-2015 rules that preceded WOTUS. ${ }^{231}$ To get an estimate, it investigated three case studies and then attempted to scale the results up to the national level. 232 The estimates did take into account the four out of ten wetlandsvaluation studies that the agencies found methodologically sound. ${ }^{233}$ Even so, the agencies were only able to quantify the effects of the their proposed rule on dredging-and-filling of wetlands and other areas, but not its effects on other types of federal regulations such as water quality. ${ }^{234}$ At this writing, professional assessments of the cost-benefit analysis have not yet appeared. Clearly, however, it varies sharply from the 2015 WOTUS analysis and seemingly, although to a lesser extent, from the initial cost-benefit analysis accompanying the advanced notice of proposed rulemaking.

228. Id. at 59 .

229. David Schultz, Trump Waters Proposal Narrower With Impact Clear as Mud, BLOOMBERG (Dec. 11, 2018), https://news.bloombergenvironment.com/environment-and-energy/trump-watersproposal-narrower-with-impact-clear-as-mud [https://perma.cc/3ZYR-VMYR].

230. U.S. ENVTL. PROT. AGENCY \& DEP'T OF THE ARMY, ECONOMIC ANALYSIS FOR THE PROPOSED REVISED DEFINITION OF “WATERS OF THE UNITED STATES” (2018), https://www.epa.gov/ sites/production/files/2018-12/documents/wotusproposedrule_ea_final 2018-12-14.pdf] [https:// perma.cc/F6WU-64VX].

231. Id. at vi. There may be some reason to doubt this assertion:

U.S. President Donald Trump's administration says it doesn't know how many streams it is proposing to exclude from Clean Water Act jurisdiction today.

But a 2017 slideshow prepared by the Environmental Protection Agency (EPA) and Army Corps of Engineers staff shows that at least $18 \%$ of streams and $51 \%$ of wetlands nationwide would not be protected under the new definition of "waters of the United States," or WOTUS, announced today.

Ariel Wittenberg \& Kevin Bogardus, EPA claims 'no data' on impact of weakening water rule. But the numbers exist, SCI. MAG. (Dec. 11, 2018), https://www.sciencemag.org/news/2018/12/epa-claims-nodata-impact-weakening-water-rule-numbers-exist [https://perma.cc/8W66-Z2U6].

232. DEP'T OF DEF. \& U.S. ENVTL. Prot. AGENCY, supra note 227, at 125.

233. Id. at 63.

234. See U.S. EnVTL. Prot. AgEnCY \& DEP'T OF THE ARMY, supra note 230, at xi. 


\section{CONCLUSION}

Of the three high-profile rules discussed in Part IV, the RIA for the Clean Power Plan replacement (ACE) may have the best claim to justify the corresponding proposed regulation, although there are some significant issues about its treatment of foreign climate impacts, its choices of discounts rates, and its treatment of co-benefits. Thus, while its economic analysis may be stronger than the others, its superiority is only relative. If independent economists are to be believed, there are glaring flaws in the analysis of the freeze on fuel efficiency standards (the SAFE rule), and the agencies themselves admit severe limitations on the cost-benefit analysis of the WOTUS replacement, such as their inability to determine how many wetlands and streams would be affected. Overall, this is not an impressive track record.

Despite some triumphalist statements about the ascendancy of costbenefit analysis, ${ }^{235}$ its status at present seems a bit shaky. As we have seen, President Trump has placed agenda controls on agencies that focus primarily on eliminating regulatory costs rather than maximizing regulatory benefits. The Administration has also begun initiatives to limit the evidence that can be considered in EPA cost-benefit analysis and to eliminate an important class of regulatory benefits from consideration. OIRA has either been unable to insist that EPA comply with its guidelines or has been overruled. The cost-benefit analyzes for major EPA deregulatory initiatives also seem to have substantial analytic gaps. While it is possible that either OIRA or the agency will correct those flaws before rules become finalized, OIRA was apparently unable or unwilling to do so at the outset. To extent that the Trump Administration has the approval of conservatives or of Republicans generally in its approach to regulatory analysis, these developments raise questions about future political support for making professionally sound cost-benefit analysis the centerpiece of the regulatory process.

There is much in the Trump Administration that deviates from normal governmental practice, ${ }^{236}$ so it may be unfair to assess either OIRA as an

235. See SUNSTEIN, supra note 49, at 3 (heralding the "revolution" brought about by cost-benefit analysis). The title of the chapter is "The Triumph of the Technocrats." Id.

236. See Daniel A. Farber, Presidential Administration Under Trump (on file with Univ. of Cal., Berkeley School of Law, Pub. Law \& Legal Theory Research Paper Series), https://ssm.com/ abstract=3015591 [https://perma.cc/X92Y-BBZ3]. 
institution or cost-benefit analysis as an analytical tool on that basis. ${ }^{237}$ Still, for those who were already skeptical of cost-benefit analysis and considered it merely a façade for blocking regulation whenever possible, the Trump experience may do little to quiet their fears. On the contrary, the experience of the Trump Administration may strengthen the argument that cost-benefit analysis is too malleable to be considered reliable. This argument may find support in the fact that EPA has been able to issue costbenefit analyzes first supporting major environmental initiatives under Obama, and then done a U-turn on the basis of new cost-benefit analysis, all with the approval of OIRA. Of course, if it turns out that none of the cost-benefit analyzes hold up in court, or even if it turns out that professional economists have a clear verdict about which ones were correct, the blame would have to shift from the methodology itself to the politics of its implementation.

With a bit less than two years of the Trump Administration behind us, it is too early to attempt a definitive verdict on its use of CBA. We will be in a much better position to pass judgment at the end of his presidency. But what we have seen so far raises serious questions both as to this Administration's practices and as to the future trajectory of federal cost-benefit analysis.

237. It bears remembering, however, that much of his regulatory policy is squarely within the mainstream of Republican Party views. For instance, Speaker Paul Ryan has also supported agencies to comply with a regulatory budget. See Tim Davaney, Speaker Ryan to Call for Major Regulatory Reforms, THE HILL (June 14, 2016), https://thehill.com/regulation/legislation/283369-speaker-ryan-to-callfor-major-regulatory-reforms [https://perma.cc/LX92-JDJC]. 
Appendix: Regulations Subject to CRA Resolutions

\begin{tabular}{|c|c|c|c|c|c|c|}
\hline $\begin{array}{l}\text { Title of } \\
\text { Regula- } \\
\text { tion }\end{array}$ & $\begin{array}{l}\text { Was tbe } \\
\text { Rule } \\
\text { Repealed } \\
\text { Using } \\
\text { CRA? } \\
\end{array}$ & $\begin{array}{l}\text { Was } \\
\text { There a } \\
\text { Semate } \\
\text { volte }\end{array}$ & $\begin{array}{l}\text { Was } \\
\text { There: } \\
\text { House } \\
\text { vote? }\end{array}$ & $\begin{array}{l}\text { Federal } \\
\text { Register } \\
\text { Cite }\end{array}$ & $\begin{array}{l}\text { RIN } \\
\end{array}$ & $\begin{array}{l}\text { Public Law } \\
\text { Cite }\end{array}$ \\
\hline $\begin{array}{l}\text { Methanc } \\
\text { and Natural } \\
\text { Gas Waste } \\
\text { Rule } \\
\end{array}$ & $\begin{array}{l}\text { No- } \\
\text { voted } \\
\text { down }\end{array}$ & $\begin{array}{l}\text { Yes- } \\
\text { voted } \\
\text { down }\end{array}$ & Yes & $\begin{array}{l}81 \text { Fed. Reg. } \\
83008\end{array}$ & $\begin{array}{l}1004- \\
\text { AE14 }\end{array}$ & $\begin{array}{l}\text { Not Appli- } \\
\text { cable }\end{array}$ \\
\hline $\begin{array}{l}\text { Fair Pay } \\
\text { snd Safe } \\
\text { Workphaces } \\
\text { EO }\end{array}$ & Yes & Yes & Yes & $\begin{array}{l}81 \text { Fed. Reg. } \\
58562\end{array}$ & $\begin{array}{l}9000- \\
\text { AM81 }\end{array}$ & $\begin{array}{l}\text { Pub. L. 115- } \\
11\end{array}$ \\
\hline $\begin{array}{l}\text { Women's } \\
\text { Health Care } \\
\text { Protections }\end{array}$ & Yes & Yes & Yes & $\begin{array}{l}81 \text { Fed. Reg. } \\
91852\end{array}$ & $\begin{array}{l}\text { 937- } \\
\text { AA04 }\end{array}$ & $\begin{array}{l}\text { Pub. L. 115- } \\
23\end{array}$ \\
\hline $\begin{array}{l}\text { Suream } \\
\text { Protection } \\
\text { Rule }\end{array}$ & Yes & Yes & Yes & $\begin{array}{l}81 \text { Fed. Reg. } \\
93066\end{array}$ & $\begin{array}{l}1029- \\
\text { AC63 }\end{array}$ & $\begin{array}{l}\text { Pub. L. 115- } \\
5\end{array}$ \\
\hline $\begin{array}{l}\text { Gun Limits } \\
\text { for the } \\
\text { Scvercly } \\
\text { Mentally III }\end{array}$ & Yes & Yes & Yes & $\begin{array}{l}81 \text { Fed. Reg. } \\
91702\end{array}$ & $\begin{array}{l}0960- \\
\text { AH95 }\end{array}$ & $\begin{array}{l}\text { Pub. L. 115- } \\
8\end{array}$ \\
\hline $\begin{array}{l}\text { Oil Anti- } \\
\text { Corruption } \\
\text { Rulo }\end{array}$ & Yes & Yes & Yes & $\begin{array}{l}81 \text { Fed. Reg. } \\
49359 \text { or } 81 \\
\text { Fed. Reg. } \\
49360\end{array}$ & $\begin{array}{l}\text { 3235- } \\
\text { AL53 }\end{array}$ & $\begin{array}{l}\text { Pub. L. 115- } \\
4\end{array}$ \\
\hline
\end{tabular}




\begin{tabular}{|c|c|c|c|c|c|c|}
\hline $\begin{array}{l}\text { Unemploy- } \\
\text { ment } \\
\text { Compensa- } \\
\text { tion Drug } \\
\text { Tcst Rules }\end{array}$ & Yes & Yes & Yes & $\begin{array}{l}81 \text { Fed. Reg. } \\
50298\end{array}$ & $\begin{array}{l}1205- \\
\text { AB63 }\end{array}$ & $\begin{array}{l}\text { Pub. L. 115- } \\
17\end{array}$ \\
\hline $\begin{array}{l}\text { BLM's } \\
\text { Land Use } \\
\text { Planning } \\
\text { Rule }\end{array}$ & Yes & Yes & Yes & $\begin{array}{l}81 \text { Fed. Reg. } \\
89580\end{array}$ & $\begin{array}{l}\text { 1004- } \\
\text { AE39 }\end{array}$ & $\begin{array}{l}\text { Pub. L. 115- } \\
12\end{array}$ \\
\hline $\begin{array}{l}\text { Wildlife } \\
\text { Rofuge OiI } \\
\text { and Gas } \\
\text { Rule } \\
\end{array}$ & No & No & No & $\begin{array}{l}81 \text { Fed. Reg. } \\
79948\end{array}$ & $\begin{array}{l}1018- \\
A \times 36\end{array}$ & $\begin{array}{l}\text { Not Appli- } \\
\text { cable }\end{array}$ \\
\hline $\begin{array}{l}\text { Drilling } \\
\text { Safeguards } \\
\text { in National } \\
\text { Parks } \\
\end{array}$ & No & No & No & $\begin{array}{l}81 \text { Fed. Reg. } \\
77972\end{array}$ & $\begin{array}{l}1024- \\
\text { AD78 }\end{array}$ & $\begin{array}{l}\text { Not Appli- } \\
\text { cable }\end{array}$ \\
\hline $\begin{array}{l}\text { Mitigation } \\
\text { Policy } \\
\text { Protecting } \\
\text { Wildlife } \\
\text { Habilats }\end{array}$ & No & No & No & $\begin{array}{l}81 \text { Fed. Reg. } \\
83440\end{array}$ & $\begin{array}{l}\text { Not } \\
\text { Availa- } \\
\text { ble }\end{array}$ & $\begin{array}{l}\text { Not Appli- } \\
\text { cable }\end{array}$ \\
\hline $\begin{array}{l}\text { Ruke to } \\
\text { Close Tax } \\
\text { Inversion } \\
\text { Loopholes }\end{array}$ & No & No & No & $\begin{array}{l}81 \text { Fed. Reg. } \\
72858\end{array}$ & $\begin{array}{l}1545- \\
\text { BN40 }\end{array}$ & $\begin{array}{l}\text { Not Appli- } \\
\text { cable }\end{array}$ \\
\hline $\begin{array}{l}\text { Drilling } \\
\text { Civil } \\
\text { Pens thies } \\
\text { Update }\end{array}$ & No & No & No & $\begin{array}{l}81 \text { Fed. Reg. } \\
50306\end{array}$ & $\begin{array}{l}1012- \\
\text { AA05 }\end{array}$ & $\begin{array}{l}\text { Not Appli- } \\
\text { cable }\end{array}$ \\
\hline $\begin{array}{l}\text { Drilling } \\
\text { Sccurity } \\
\text { and Safety } \\
\text { Standards }\end{array}$ & No & No & No & $\begin{array}{l}81 \text { Fed. Reg. } \\
81356\end{array}$ & $\begin{array}{l}1004- \\
\text { AE15 }\end{array}$ & $\begin{array}{l}\text { Not Appli- } \\
\text { cable }\end{array}$ \\
\hline $\begin{array}{l}\text { ESSA } \\
\text { Accounta- } \\
\text { bility and } \\
\text { Stalc Plan } \\
\text { Rulos }\end{array}$ & Yes & Yes & Yes & $\begin{array}{l}81 \text { Fed. Reg. } \\
86076\end{array}$ & $\begin{array}{l}1810 \\
\text { AB27 }\end{array}$ & $\begin{array}{l}\text { Pub. L. 115- } \\
13\end{array}$ \\
\hline
\end{tabular}




\begin{tabular}{|c|c|c|c|c|c|c|}
\hline $\begin{array}{l}\text { ESSA } \\
\text { Teacher } \\
\text { Preparalion } \\
\text { Standards }\end{array}$ & Yes & Yes & Yes & $\begin{array}{l}81 \text { Fed. Reg. } \\
75494\end{array}$ & $\begin{array}{l}1840- \\
\text { AD07 }\end{array}$ & $\begin{array}{l}\text { Pub. L. 115- } \\
14\end{array}$ \\
\hline $\begin{array}{l}\text { Chemical } \\
\text { Facility } \\
\text { Safoguards }\end{array}$ & No & No & No & $\begin{array}{l}82 \text { Fed. Reg. } \\
4594\end{array}$ & $\begin{array}{l}2050- \\
\text { AG82 }\end{array}$ & $\begin{array}{l}\text { Not Appli- } \\
\text { cable }\end{array}$ \\
\hline $\begin{array}{l}\text { Mitigation } \\
\text { Policy } \\
\text { Protecting } \\
\text { Endangerod } \\
\text { Specics }\end{array}$ & No & No & No & $\begin{array}{l}81 \text { Fed. Reg. } \\
95316\end{array}$ & $\begin{array}{l}\text { Not } \\
\text { Availa- } \\
\text { ble }\end{array}$ & $\begin{array}{l}\text { Not Appli- } \\
\text { cable }\end{array}$ \\
\hline $\begin{array}{l}\text { State } \\
\text { Retirement } \\
\text { Savings } \\
\text { Plans Rules } \\
\text { - } 81 \text { Fed. } \\
\text { Reg. } 92639\end{array}$ & Yes & Yes & Yes & $\begin{array}{l}81 \text { Fed. Reg. } \\
92639\end{array}$ & $\begin{array}{l}1210 \\
\text { AB76 }\end{array}$ & $\begin{array}{l}\text { Pub. L. 115- } \\
24\end{array}$ \\
\hline $\begin{array}{l}\text { State } \\
\text { Retirement } \\
\text { Savings } \\
\text { Plans Rules } \\
\text { - } 81 \text { Fed. } \\
\text { Reg. } 59464\end{array}$ & Yes & Yes & Yes & $\begin{array}{l}81 \text { Fed. Reg. } \\
59464\end{array}$ & $\begin{array}{l}1210- \\
\text { AB71 }\end{array}$ & $\begin{array}{l}\text { Pub. L. 115- } \\
35\end{array}$ \\
\hline $\begin{array}{l}\text { Oil Drilling } \\
\text { Measure- } \\
\text { ment } \\
\text { Standards }\end{array}$ & No & No & No & $\begin{array}{l}81 \text { Fed. Reg. } \\
81516\end{array}$ & $\begin{array}{l}1004 \\
\mathrm{AE} 17\end{array}$ & $\begin{array}{l}\text { Not Appli- } \\
\text { cable }\end{array}$ \\
\hline $\begin{array}{l}\text { Alaska } \\
\text { National } \\
\text { Wildlife } \\
\text { Refuges } \\
\text { Rule } \\
\end{array}$ & Yes & Yes & Yes & $\begin{array}{l}81 \text { Fed. Reg. } \\
52247\end{array}$ & $\begin{array}{l}\text { 1018- } \\
\text { BA31 }\end{array}$ & $\begin{array}{l}\text { Pub. L. } \\
115-20\end{array}$ \\
\hline
\end{tabular}




\begin{tabular}{|c|c|c|c|c|c|c|}
\hline $\begin{array}{l}\text { Arctic } \\
\text { Drilling } \\
\text { Safcguards }\end{array}$ & No & No & No & $\begin{array}{l}81 \text { Fed. Reg. } \\
46477\end{array}$ & $\begin{array}{l}1082- \\
\text { AA00 }\end{array}$ & $\begin{array}{l}\text { Not Appli- } \\
\text { cable }\end{array}$ \\
\hline $\begin{array}{l}\text { Coal } \\
\text { Valuation } \\
\text { Ruke }\end{array}$ & No & No & No & $\begin{array}{l}81 \text { Fed. Reg. } \\
43337\end{array}$ & $\begin{array}{l}1012- \\
\text { AA13 }\end{array}$ & $\begin{array}{l}\text { Not Appli- } \\
\text { cable }\end{array}$ \\
\hline $\begin{array}{l}\text { Prepaid } \\
\text { Card Ruke }\end{array}$ & No & No & No & $\begin{array}{l}81 \text { Fed. Reg. } \\
83934\end{array}$ & $\begin{array}{l}3170- \\
\text { AA22 }\end{array}$ & $\begin{array}{l}\text { Not Appli- } \\
\text { cable }\end{array}$ \\
\hline $\begin{array}{l}\text { ACF River } \\
\text { Basin Watcr } \\
\text { Control } \\
\text { Standards }\end{array}$ & No & No & No & Not Available & $\begin{array}{l}\text { Not } \\
\text { Availa- } \\
\text { ble }\end{array}$ & $\begin{array}{l}\text { Not Appli- } \\
\text { cable }\end{array}$ \\
\hline $\begin{array}{l}\text { Gas Drilling } \\
\text { Measure- } \\
\text { ment } \\
\text { Standards }\end{array}$ & No & No & No & $\begin{array}{l}\text { 81 Fed. Reg. } \\
81462\end{array}$ & $\begin{array}{l}\text { 1004- } \\
\text { AE } 16\end{array}$ & $\begin{array}{l}\text { Not Appli- } \\
\text { cable }\end{array}$ \\
\hline $\begin{array}{l}\text { OSHA } \\
\text { Record- } \\
\text { kecping } \\
\text { Rule }\end{array}$ & Yes & Yes & Yes & $\begin{array}{l}81 \text { Fed. Reg. } \\
91792\end{array}$ & $\begin{array}{l}1218- \\
\text { AC84 }\end{array}$ & $\begin{array}{l}\text { Pub. L. } \\
115-21\end{array}$ \\
\hline $\begin{array}{l}\text { Cross-State } \\
\text { Air } \\
\text { Pollution } \\
\text { Update }\end{array}$ & No & No & No & $\begin{array}{l}81 \text { Fed. Reg. } \\
74504\end{array}$ & $\begin{array}{l}2060- \\
\text { AS05 }\end{array}$ & $\begin{array}{l}\text { Not Appli- } \\
\text { cable }\end{array}$ \\
\hline $\begin{array}{l}\text { Broadband } \\
\text { Privacy } \\
\text { Protections }\end{array}$ & Yes & Yes & Yes & $\begin{array}{l}81 \text { Fed. Reg. } \\
87274\end{array}$ & $\begin{array}{l}\text { Not } \\
\text { Availa- } \\
\text { ble }\end{array}$ & $\begin{array}{l}\text { Pub. L. } \\
115-22\end{array}$ \\
\hline $\begin{array}{l}\text { Utah } \\
\text { Regional } \\
\text { Haze Rule }\end{array}$ & No & No & No & $\begin{array}{l}81 \text { Fed. Reg. } \\
43893\end{array}$ & $\begin{array}{l}\text { Not } \\
\text { Availa- } \\
\text { ble }\end{array}$ & $\begin{array}{l}\text { Not Appli- } \\
\text { cable }\end{array}$ \\
\hline $\begin{array}{l}\text { Encrgy } \\
\text { Efliciency } \\
\text { Test } \\
\text { Procedures } \\
\text { for } \\
\text { Compres- } \\
\text { sors }\end{array}$ & No & No & No & $\begin{array}{l}82 \text { Fed Reg. } \\
1052\end{array}$ & $\begin{array}{l}\text { 1904- } \\
\text { AD43 }\end{array}$ & $\begin{array}{l}\text { Not Appli- } \\
\text { cable }\end{array}$ \\
\hline
\end{tabular}




\begin{tabular}{|l|l|l|l|l|l|l|}
\hline $\begin{array}{l}\text { Arbitration } \\
\text { Ruke }\end{array}$ & Yes & Yes & Yes & $\begin{array}{l}82 \text { Fed. Reg. } \\
33210\end{array}$ & $\begin{array}{l}3170- \\
\text { AA51 }\end{array}$ & $\begin{array}{l}\text { Pub. L. } \\
115-74\end{array}$ \\
\hline $\begin{array}{l}\text { Payday } \\
\text { Lending } \\
\text { Rules }\end{array}$ & No & No & No & $\begin{array}{l}82 \text { Fed. Reg. } \\
54472\end{array}$ & $\begin{array}{l}3170- \\
\text { AA40 }\end{array}$ & $\begin{array}{l}\text { Not Appli- } \\
\text { cable }\end{array}$ \\
\hline $\begin{array}{l}\text { Net } \\
\text { Neutrality }\end{array}$ & No & Yes & No & $\begin{array}{l}83 \text { Fed. Reg. } \\
7852\end{array}$ & $\begin{array}{l}\text { Not } \\
\text { Availa- } \\
\text { ble }\end{array}$ & $\begin{array}{l}\text { Not Appli- } \\
\text { cable }\end{array}$ \\
\hline $\begin{array}{l}\text { Indircet } \\
\text { Auto } \\
\text { Lending } \\
\text { Guidance }\end{array}$ & Yes & Yes & Yes & Not Available & $\begin{array}{l}\text { Availa- } \\
\text { ble }\end{array}$ & $\begin{array}{l}\text { Pub. L. } \\
115-172\end{array}$ \\
\hline
\end{tabular}




$$
\text { - }
$$

